\title{
SZINUSZHULLÁMÚ ÉS AMPLITÚDÓMODULÁLT BESZÉD ÉSZLELÉSÉNEK VIZSGÁLATA MAGYAR MONDATOK SEGÍTSÉGÉVEL
}

\section{JAKAB ZOLTÁN ${ }^{1}$ - NAGYNÉ RINGGER GABRIELLA ${ }^{2}$ - VÍG JULIANNA ${ }^{1}$ - SZABÓ PÁL TAMÁS ${ }^{3}$}

\author{
${ }^{1}$ Eötvös Loránd Tudományegyetem, Bárczi Gusztáv Gyógypedagógiai Kar, \\ ${ }^{2}$ Pedagógiai Szakszolgálat, Budapest, XVII. kerület, \\ ${ }^{3}$ Szent János Kórház és Észak-Budai Egyesített Kórházak, Neurológiai Osztály \\ E-mail: jakab.zoltan@barczi.elte.hu
}

Beérkezett: 2017. október 18. - Elfogadva: 2018. január 20.

Online megjelenés: 2018. május 17.

Háttér és célok: Kutatásunkban elszegényített beszédingerek két típusát használtuk gyerekek és felnôtttek beszédészlelési képességének vizsgálatára.

Módszer: Vizsgálatunkat 5-6 éves gyermek és felnôtt mintán végeztük, szinuszhullámú és amplitúdómodulált beszédingerek - magyar nyelvú mondatok - segítségével. Beszédingereinket természetes kiejtésú változatokból szintetizáltuk.

Eredmények: Korábbi angol nyelvú vizsgálatok eredményeihez hasonlóan azt tapasztaltuk, hogy mindkét korcsoport igen jól érti ezeket a szintetizált beszédfajtákat, bár a felnôttek jobban teljesitenek a gyerekeknél. Ugyanakkor adataink eltérö képet mutatnak a kétféle szintézistípus viszonyáról az angol nyelvú vizsgálatokhoz képest. Míg angol anyanyelvú mintáknál a gyerekek a szinuszhullámú beszédet relatíve jobban értették, mint az amplitúdómoduláltat, felnôtteknél pedig ez a viszony megfordult, a magyar nyelvú vizsgálatok esetén gyerekeknél egyforma teljesítményt találtunk a kétféle ingertípusra, míg felnôtteknél az amplitúdómodulált ingerek elönyét találtuk (lehetséges ugyanakkor, hogy ez csak az ingernehézségi paraméterek eltérô beállitásának következménye). A lexikai restaurációs hatásokat jelezte, hogy a mondatok elsố fönévi csoportjának felismerése igen erösen korrelált a mondatok további részének felismerésével.

Konklúzió: Adataink részben reprodukálják az angol nyelven végzett vizsgálatok eredményeit. Új eredményként kétféle perceptuális tanulási hatást sikerült elkülönítenünk: az azonnali perceptuális tanulás gyerekeknél és felnôtteknél is megfigyelhetố, míg a próbák során jelentkezố gyakorlási, tehát az egyes mondatok közötti transzferhatás csak felnốtteknél.

Kulcsszavak: szinuszhullámú beszéd, amplitúdómodulált beszéd, beszédészlelés, peceptuális tanulás 


\section{BEVEZETÉS}

A beszédészlelés vizsgálatában számos adat, megfigyelés utal arra, hogy az emberi beszédet nehezített körülmények között is igen jól meg tudjuk érteni. Ennek egyik alapvetô példája a zajos környezetben hallható beszéd (Nilsson, Soli és Sullivan, 1994; Nilsson, Soli és Gelnett 1996; Gósy, 1995). Elméleti szempontból talán még érdekesebb eset az, amikor több személy egyidejú beszédéból szúrjük ki és követjük az egyikük hangját (ez az ún. koktélparti helyzet, lásd Cherry, 1953). A koktélparti jelenség azt is jelzi, hogy képesek vagyunk dinamikusan változtatni a jel és a zaj kijelölését és az ennek alapján való szúrést a beszédészlelés során. Ez pedig felveti azt a kérdést, hogy melyek azok az ingerjellemzók, melyek alapján a beszédet beszédként ismerjük föl, és a benne lévô különbözố szegmenseket kiemeljük, azonosítjuk. Utóbbi kérdés az elszegényített szintetikus beszédingerek vizsgálata útján közelíthetô meg; ezeknek két közismert formája a szinuszhullámú beszéd ( sine-wave speech, SWS) és az amplitúdómodulált beszéd (vocoded speech, VOC, illetve más helyeken amplitude envelopes, AE; Remez, Rubin, Pisoni és Carrell, 1981; Shannon, Zeng, Kamath, Wygonski és Ekelid, 1995). Mára mindkettônek számos variánsa létezik, de eredeti formában a szinuszhullámú beszéd elsôsorban a természetes beszéd formánsainak idôben lassabb frekvenciaváltozásait (az ún. dinamikus spektrális struktúrát; Nittrouer és Lowenstein, 2010) ôrzi meg, míg az amplitúdómodulált beszéd épp ezeket mossa el kisebb-nagyobb mértékben, és a természetes beszéd amplitúdóváltozásait ôrzi meg, néhány elôre kijelölt frekvenciasávban. ${ }^{1}$ Mindkét típusú beszédszintézist használják a beszédészlelés vizsgálatában; mára angol nyelvú anyagon angol anyanyelvú kísérleti személyekkel számos vizsgálat született (Remez és mtsai, 1981; Remez, Rubin, Nygaard és Howell, 1987; Remez, Rubin, Berns, Pardo és Lang, 1994; Remez és Rubin, 1990; Shannon és mtsai, 1995; Rosner és mtsai, 2003; Nittrouer, Lowenstein és Packer, 2009; Nittrouer és Lowenstein, 2009, 2010; Hervais-Adelman, Davis, Johnsrude, Taylor és Carlyon, 2011; Hillenbrand, Clark és Baer, 2011; Lowenstein, Nittrouer és Tarr, 2012; Newman, Chatterjee, Morini és Nasuta, 2013). Létezik ugyanakkor néhány nyelvközi összehasonlítás is, ezek az angol mellett német, illetve mandarin kínai nyelven gyújtöttek adatokat (Bent, Loebach, Phillips és Pisoni, 2011; Rosen és Hui, 2015).

\section{Klasszikus beszédészlelési vizsgálatok szinuszhullámú beszéddel}

A beszédészlelés az inger összetett temészetéból fakadóan hierarchikus folyamat, melyben az akusztikai jellemzôk elemzését követi a fonetikai jegyek azonosítása, majd a nyelvspecifikus szabályokon alapuló fonémadöntés (Gósy, 2005; Johnson, 2010; Remez, 2005). Már az 1980-as években is ismert volt, hogy míg a fonetikai kategorizáció

Kissé árnyalja ezt a képet, hogy a szinuszhullámú beszéd elôállítására szolgáló algoritmusok általában meghagyják a formánsok amplitúdóváltozásainak egy részét, tehát a szinuszhullámmal közelített formánsok amplitúdója egy-egy ilyen ingeren belül nem konstans. Legalábbis alapesetben nem az, de a szintézis algoritmusának megfelelô beállításával az amplitúdók konstanssá tehetôek (Remez és Rubin, 1990). 
számos egyszerúbb jelensége kiváltható nem beszédjellegú ingerekkel, a fonetikai feldolgozás összetettebb jelenségei már csak beszédingerek esetében figyelhetôek meg. Repp (1982) például amellett érvel, hogy a beszédjellegú és nem beszédjellegú ingerek feldolgozására két elkülönült feldolgozási módot használunk, és léteznek olyan ingerek, melyek megfelelő kontextusban bemutatva e kettô közül bármelyiket, illetve akár egyszerre mindkettôt is aktiválják. A szinuszhullámú beszéd különösen alkalmas ennek a jelenségnek a vizsgálatára; ugyanis naiv hallgatók ezt nem automatikusan kezelik beszédingerként, csak akkor, ha erre előzetes instrukcióval felhívják a figyelmüket. Sốt, az ún. fonetikai kölcsönhatások ${ }^{2}$ egyazon inger esetében is megfigyelhetốek akkor, ha azt beszédként észleljük, és nem figyelhetôek meg, ha a hallgató nem ismeri fel, hogy beszédról van szó. Ezekhez szorosan kapcsolódó, és ugyancsak a kétféle percepciós mechanizmus meglétét támogató evidencia az ún. „duplex percepció”, mely a vizuális modalitásban megjelenó multistabil percepció auditoros megfelelóje (Repp, 1982; Remez és mtsai, 1994; Schwartz, Grimault, Hupe, Moore és Pressnitzer, 2012). A duplex percepció jelensége azt jelenti, hogy egy ingert megjelenésekor egyszerre hallunk beszédnek és nem beszédjellegú ingernek. Ilyen észlelés figyelhetô meg, ha például egy szintetizált szótag egyik akusztikus összetevőjét (például a formánsátmenetet) az egyik fülbe, míg a többi összetevốt a másik fülbe játsszuk le. Ilyenkor a személy két dolgot hall egyszerre: a szótag egészét, és ezzel egy idôben a formánsátmenet ciripelésre emlékeztetô hangját.

Felvetôdhet a kérdés, hogy ezek a feldolgozási szintek a hallórendszeren (illetve nyelvi rendszeren) belül mennyiben felelnek meg a mentális modularitás kritériumainak, tehát mennyiben tekinthetôek elkülönült moduloknak. Remez és munkatársai (1994) szerint a két feldolgozási szint egyaránt gyors és területspecifikus annyiban, hogy eltérô perceptuális integrációs elvek szerint múködik. Remez és munkatársai ugyanis amellett érvelnek, hogy a hallásijelenet-elemzés (Bregman, 1990; magyarul lásd Honbolygó, 2007a, 330) elvei nem magyarázzák meg a szinuszhullámú beszéd észlelésének jelenségét, azt tehát, hogy három, idôben egymástól függetlenül változó frekvenciájú szinuszhullámot koherens beszédként vagyunk képesek észlelni. A beszédészlelés során fellépô perceptuális integráció más elvek szerint múködik. Másfelôl viszont a szinuszhullámú beszéd észlelésének instrukcióérzékenysége azt mutatja, hogy a beszédészlelésért felelôs mechanizmusok nem automatikusak, és nem is magukba zártak. Tehát feldolgozási szintekrôl beszélhetünk, ám fodori értelemben vett modulokról kevésbé. Kifinomult kísérleti technikákkal e feldolgozási szintek tovább is tagolhatóak. Így például Samuel és Kat (1996) a szintetikus /ba/-/da/ kontinuumban megfigyelhetố adaptációs hatásokat vizsgálva összetett kritériumot használt: (i) az adaptáció csak monaurálisan avagy interaurálisan is megfigyelhetô-e, és (ii) hogyan jelenik meg az adaptáció a kategóriahatár-változásban, illetve a reakcióidóben. Kísérletsorozatuk alapján a szerzôk három feldolgozási szintet javasoltak: (1) egy monaurális

A 'phonetic trading relations' terminus fordítása (Repp, 1982). Szinte mindegyik fonetikai kontraszt (pl. szár-sztár) esetén több akusztikai jegy is segíti a megkülönböztetést. Az egyes akusztikus jegyek egymás hatását erôsíteni, illetve ellensúlyozni is képesek. Például a szár-sztár pár esetében az /sz/ hang utáni megnövekedett szünet valószínúbbé teszi, hogy 'sztár'-t hallunk, ám azt bizonyos határon belül ellensúlyozni lehet az /á/ hang elsố formánsa (F1) frekvenciájának megváltoztatásával (például szintetizált beszédben; Morrongiello, Robson és Best, 1984). 
akusztikus elemzó szintet (ezt nemfonetikus adaptorok hajtották meg, és csak reakcióidô-változást eredményezett a /ba/-/da/ döntésben); (2) egy binaurális, integratív-akusztikus szintet: ezt is nemfonetikus adaptorok befolyásolták, de itt az adaptáció kontralaterálisan is megfigyelhetô volt, és nemcsak a reakcióidốt lassította, hanem a kategóriahatárt is eltolta; végül (3) egy binaurális fonetikus szintet, melyre csak fonetikus adaptorok hatottak, és ahol az adaptáció csak a kategóriahatár változásában mutatkozott meg.

Ebbe a tágabb elméleti keretbe illeszkedett tehát Remez és munkatársai számos vizsgálata az 1980-as, 1990-es években. A beszédészlelés elkülönült feldolgozási szintjét véleményük szerint az is alátámasztotta, hogy a szinuszbeszédet annak ellenére értjük - s ebben az értelemben koherensen észleljük -, hogy az inger akusztikus struktúráját a hallásijelenet-elemzés elvei nem képesek egységes mintázattá integrálni (Remez és mtsai, 1994; magyarul lásd Honbolygó, 2007b, 369). A beszédészlelés során fellépố perceptuális integrációnak tehát más elvek szerint kell haladnia. Ilyen elv lehet például, hogy a három szinuszformáns szinte a valóságosnál is kontrasztosabban, egyértelmúbben jeleníti meg az eredeti mondat globális formánsstruktúráját; ez fontos támpont lehet a megértésben. Egészében tehát a szinuszhullámú beszéd „beszédszerû" idôi mintázatot mutat, annak ellenére, hogy a formánsok felharmonikusai és a mássalhangzók zörejkomponenseinek túlnyomó többsége hiányzik belôle. A három szinuszformáns mellett ugyanakkor fontos szerepe van a felismerhetôségben a zárhangoknak megfelelố szüneteknek, amelyek alatt a szinuszformánsok amplitúdója is minimálisra csökken (Remez és Rubin, 1990). Szintén a beszédfeldolgozás sajátosságait mutatja szinuszbeszéd esetében a forrásnormalizáció (speaker normalization) megléte (Remez és mtsai, 1987); a klasszikus, Ladefoged és Broadbent (1957) által végzett „/bit/-/bet/-/bat/-/but/" kísérlet ugyanis szinuszhullámú ingerekkel részben megismételhetônek bizonyult, és az eredmények alapján levonható a következtetés, hogy normalizációs hatások szinuszhullámú beszéd esetén is múködnek.

\section{Szintetizált beszéd: fejlödési jelenségek}

A beszédészlelés fejlôdésével kapcsolatos vizsgálatok egyik felvetése az, hogy a különbözô akusztikus ingerjegyek súlyozása a fonetikai döntésekben jellegzetes életkori változásokat mutat, és ez összefügghet a befogadó anyanyelvével, az abban való korai tapasztalatszerzéssel (Nittrouer és Lowenstein, 2009). Két ilyen jellegzetes ingervonás a formánsátmenetek, illetve a mássalhangzók zörejkomponensei. Ezek súlyozása a beszédészlelési feldolgozásban különbözik kisgyerekek és felnôttek között. Nittrouerék adatai szerint három- és ötévesek nagyobb mértékben hagyatkoztak a formánsátmenetekre, és kisebb mértékben a zörejkomponensekre, mint hétévesek és felnôttek, ha CV szótagok azonosítása a feladat. E jelenségek vizsgálata a természetes beszéd észlelése mellett szinuszhullámú, amplitúdómodulált, illetve egyéb módon nehezített (pl. suttogva kiejtett) beszédingerekkel történhet. Nittrouerék e vizsgálatában a természetes beszéd mellett szinuszhullám-szintézist és természetes suttogó beszédet használtak az ingerként használt szótagok előállítására. Eredményeik szerint öt- és hétévesek akkor is kitartottak a formánsátmenetekre alapozott fonémadöntés mellett, ha 
a formánsátmeneteket szinuszhullámú szintetizált formában hallották, míg felnôttek ebben az esetben kevésbé vették figyelembe a formánsátmeneteket, mint a természetes kiejtésben. A természetes kiejtés, illetve suttogó beszéd összevetése ezzel ellentétes eredményt adott: itt a felnôttek mindkét esetben egyenlô mértékben hagyatkoztak a formánsátmenetre, míg a gyerekek (5 és 7 évesek) sokkal kevésbé használták a formánsátmeneteket a fonetikai kategorizációban, ha zöngés természetes kiejtésrôl suttogó beszédre váltottak az ingerek. Ez az eredmény számos fontos megfigyelést foglal magában. Egyrészt a szinuszhullámú formánsok egyáltalán nem hangzanak természetesen a gyerekek számára, mégis erôsen használják ôket a fonémadöntésben, míg a suttogó beszédben megjelenó elmosódottabb, zaj jellegú formánsokat annak ellenére sem használják, hogy a suttogó beszéd hangzása ismerôs lehet számukra. Mind a szinuszhullám-szintézis, mind a suttogás eliminálja a természetes, zöngés formánsok egyik alapvetô akusztikus tulajdonságát, nevezetesen a harmonikus szerkezetet (a felharmonikusok sorát, mely a beszélố hangszínének meghatározásában is fontos szerepet játszik). Bár a harmonicitást mindkét transzformáció eltünteti, mégis az egyik esetben a gyerekek kitartanak a formánsátmenetekre való fókusz mellett, a másikban nem. A különbség oka az lehet Nittrouerék szerint, hogy míg a szinuszbeszédben a formánsok élesen elkülönülnek egymástól, így frekvenciáik idôbeli változása jól követhetô (tulajdonképpen még a természetes beszédnél is jobban), addig a suttogásban a formánsok csak elmosódott, zajszerú formában jelennek meg. A gyerekek pedig, értelmezésük szerint, a jól követhetô, idôben lassabb, dinamikus frekvenciamodulációra érzékenyebbek, míg a zajszerú elemekre kevésbé. Ezzel szemben a felnôttek jobban fókuszálnak a zajszerú ingerjegyekre, és valamivel kevésbé a frekvenciaváltozásokra. Ezzel a következtetéssel Nittrouerék lényegében csatlakoznak Remez és munkatársai kritikájához a hallásijelenet-elemzéssel kapcsolatban. Ugyanis a bregmani felfogás szerint a harmonikus struktúra a hallási perceptuális integráció egyik alapvetô vezérfonala, míg Nittrouerék adatai szerint a szótagok észlelésében egyáltalán nem játszik meghatározó szerepet. Késôbbi vizsgálataikban a szerzôk (Nittrouer és mtsai, 2009; 2010; Lowenstein és mtsai, 2012) ezt az alapkövetkeztetést értelmes és értelmetlen mondatok vizsgálatával, illetve a szintézis módjának változtatásával is megerôsítették. Létezik ennek a tendenciának ellentmondó adat is, 27 hónapos gyerekek vizsgálatából, akik még nem mutatták a szinuszhullámú beszéd felismerési elônyét az amplitúdómodulálttal szemben (Newman és mtsai, 2013). Ezt az eltérést az utóbbi vizsgálat szerzôi módszertani különbségekkel magyarázták (pl. az ô feladatukban egy célszó hatására kellett a tipegố korú személyeknek a két kép közül a megfelelőre nézni). Ez azonban véleményünk szerint nem tûnik kielégítô magyarázatnak, ${ }^{3}$ így felvetôdhet, hogy két- és hároméves kor között is vannak életkori különbségek a beszédészlelési stratégiákban.

E fejlődési megfontolások felvetik azt a kérdést is, hogy az egyes nyelvek nem különböznek-e a súlyozási stratégiák tekintetében. Nittrouerék szerint igen: a gyerekeknek a nyelvelsajátítás korai idôszakában, lényegében már csecsemôkortól kezdve rá kell

A Nittrouer-féle szótagos vizsgálatban (Nittrouer és Lowenstein, 2009) zárt válaszkészletet használtak (mindössze négy szótag közül lehetett választani); ugyanebben a vizsgálatban nem volt kontextushatás sem. Ennek ellenére ellentétes eredményt kaptak, mint Newmanék (2013). Más magyarázatra van tehát szükség; lehet, hogy 2 és 3 évesek között van valamilyen életkori különbség. 
találniuk azokra az észleléses jegyekre, amelyek az adott anyanyelvi környezetben a legrelevánsabbak a jelentés és nyelvtani szerkezet rekonstrukciója szempontjából, és ezeket a jegyeket fogják a legalaposabban feldolgozni, vagyis nagyobb súllyal fogják figyelembe venni, mint a kevésbé releváns vonásokat (Nittrouer és Lowenstein, 2009). Ugyanakkor a súlyozási stratégiák nyelvek közti különbségeirôl minimális adat áll csak rendelkezésre, magyar nyelven pedig egyáltalán nincs még ezzel kapcsolatos vizsgálat. Ez motivációt jelenthet arra, hogy a késôbbiekben e fenti vizsgálatokhoz hasonlót magyar nyelven is elvégezzünk.

Egy ehhez szorosan kapcsolódó kérdés az angol és a magyar nyelv közti hangtani különbségeknek a megértésre gyakorolt hatása. A magyar és az angol nyelv kiejtése, illetve hangrendszere között számos olyan különbség van, melyek a beszédértés, és különösen a szinuszhullámú vagy amplitúdómodulált beszéd megértése szempontjából kritikusak. Például az angolban bizonyos magánhangzók, illetve kettôshangzók kiejtésének hosszát befolyásolja hangsúlyos szótagban a közvetlenül utánuk következó mássalhangzó zöngéssége: ugyanazt a magán- vagy kettôshangzót hosszabban ejtik zöngés, mint zöngétlen mássalhangzó elôtt. Például rövid magánhangzók megnyúlnak szóvégi zöngés mássalhangzó elôtt: 'sad', 'lab', zöngétlen elốtt azonban nem változnak: 'sat', 'lap'. Magyarban nincs ilyen különbség: 'rak' vs. 'rag'; 'kéz' vs. 'kész', 'hat' vs. 'had'. Egy másik közismert példa a hangsúlyozás különbsége: az angolban, szemben a magyarral, nem mindig az elsố szótag hangsúlyos. Sôt, a hangsúlynak viszonylag szisztematikus jelentésmegkülönböztetô szerepe is van, például ige-fônév párok esetén: / 'permit/ (fönév) vs. /per'mit/ (ige); / 'record/ (fönév) vs. /re'cord/; / 'present/ (fốnév) vs. /pre'sent/ (ige). Egy harmadik, számunkra roppant fontos különbség, hogy az angol szavak kiejtés szempontjából általában „közelebb” vannak egymáshoz, mint a magyarok. Ez azt jelenti, hogy egyrészt az angolban több beszédhang van (fóleg magánhangzóból), mint a magyarban. Ugyanakkor az angol szavak átlagosan rövidebbek, mint a magyarok, így angolban gyakrabban fordul eló, hogy ha egy szó valamely hangját kicsit másképp ejtjük, akkor akaratlanul is egy másik szóhoz jutunk. ${ }^{4}$ Késóbbi kutatásokban az ilyen típusú különbségekre (azok megértéssel való kapcsolatára) vonatkozóan specifikus hipotéziseket is meg lehet fogalmazni. Jelen vizsgálatunk az elsô lépés a nyelvközi különbségek vizsgálata irányába, de hangsúlyoznunk kell, hogy itt most elsôsorban a fejlôdés egy másik aspektusára, nevezetesen a gyors perceptuális tanulásra voltunk kíváncsiak.

\section{Azonnali perceptuális tanulás}

A redukált beszédformák észlelésével, illetve ennek fejlődősével kapcsolatban felmerül a perceptuális tanulás kérdése is: vajon hogyan és milyen mértékben képesek különbözô életkorú személyek teljesítményjavulásra. Ezzel kapcsolatban az egyik legérdekesebb jelenség a következô. Sok személy elôször hallván például egy szinuszhullámú mondatot, abból semmit nem ért; ha ezután meghallgatja ugyanazt a mondatot

4 Tömör magyar nyelvú forrás errôl: http://idegennyelvor.blog.hu/2009/06/27/kulonbsegek_angol_es_magyar_kiejtese_kozott.Szakmailag alapos áttekintést ad a témáról Canepari, 2007. 

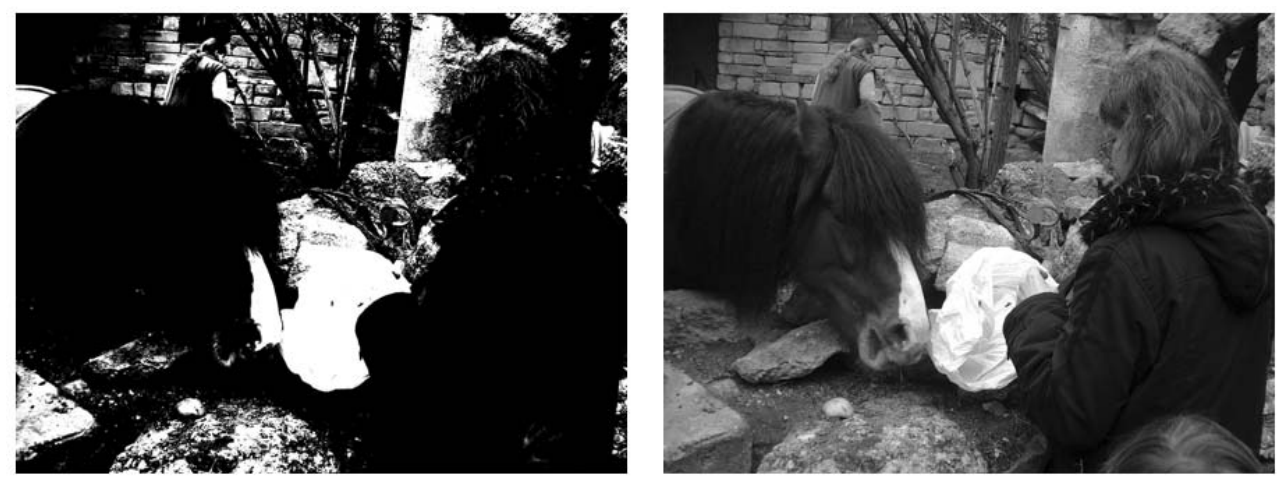

1. ábra. Kéttónusú, ún. Mooney-kép és eredeti, tónusgazdag változata (A szerzốk saját felvétele)

természetes kiejtésben, majd ismét a szinuszhullámú változatot, akkor utóbbit már tökéletesen érti, és ezt egy „aha” élmény kíséri. Ennek a jelenségnek van egy vizuális párhuzama, és ennek kapcsán nevet is kapott: Craig M. Mooney kanadai pszichológus kéttónusú képeket mutatott kísérleti személyeinek, melyeket azok nem voltak képesek felismerni; viszont a képek tónusgazdag változatainak bemutatása után nyilvánvalóvá vált számukra, hogy mit ábrázolnak a kéttónusú képek (1. ábra; Mooney, 1957).

E jelenség fố vonásai a következôk: a tónusgazdag kép egyszeri bemutatása teljesen megváltozatta az eredeti, elszegényített inger észelését, holott maga az eredeti inger egyáltalán nem változott. Ez a változás azonnali volt, erôfeszítést nem igényelt. A hatás a megfigyelések szerint tartós is volt, tehát akár évekkel a tónusgazdag kép elsố bemutatását követôen is kimutatható volt. Mooney ezt a hatást azonnali perceptuális tanulásnak (instant learning; „one-shot” learning) nevezte el. Kovács Ilona és munkatársai egy 8 foós mintán alapuló vizsgálatukban úgy találták, hogy ez az azonnali tanulási hatás 4-5 éves gyerekeknél még nem figyelhetô meg; ôk akkor sem ismerik fel az elszegényített képet, ha egymás mellett mutatják be a tónusgazdag és az elszegényített képet (Kovács és Eisenberg, 2004). Kovács és munkatársai szerint e különbségnek két oka lehet: (i) az alacsony szintú perceptuális integráció csökkent mértéke, vagy (ii) a magas szintú integráció, a tárgyészlelési tapasztalatot igénylô perceptuális kategóriák (vagyis a top-down hatások) éretlensége. Errôl a területrôl azonban hiányoznak a további kutatások. Annyit látunk tehát, hogy az azonnali perceptuális tanulás felnốtteknél mindkét modalitásban megjelenik, gyerekeknél pedig vizuális ingerek esetén valószínúleg nem. Mi tehát a helyzet a szinuszbeszéd észlelésével gyerekek esetében? Az elôzô részben idézett fejlôdési adatokból úgy tûnik, hogy beszédingerek esetében gyerekeknél is többé-kevésbé megfigyelhetô az azonnali tanulási hatás (Nittrouer és munkatársai 3 és 7 éves kor közötti életkori tartományban vizsgálódtak); a természetes kiejtés meghallgatása határozottan javította elsôsorban a szinuszhullámú beszéd megértését gyerekeknél. A beszédészlelés fejlôdésének jelen cikkben bemutatott vizsgálata pont ezt az aspektust vizsgálja, tehát hogy a redukált beszédformák észlelése során milyen különbségek figyelhetőek meg a perceptuális tanulásban gyerekek és felnôttek között. 
Összefoglalva tehát, vizsgálatunk célja az volt, hogy magyar ingeranyagon, kétféle redukált beszédinger segítségével hasonlítsuk össze gyerekek és felnôttek beszédészlelési teljesítményét. A magyar nyelven végzett vizsgálat értelme az lehet, hogy egy, az angoltól eltérô hangtani sajátosságokkal rendelkezô nyelv esetén a kétféle szintézis eltérô hatással lesz a teljesítményre, és a különbségek értelmezhetôek is lesznek. A teljesítményen belül egyrészt az életkorral való általános javulásra voltunk kíváncsiak (ez az angol nyelven végzett vizsgálatokban is központi helyen állt), másrészt a perceptuális tanulás jelenségeire; ezt valamivel alaposabban elemeztük, mint a korábbi kutatások szerzói.

\section{MÓDSZER}

\section{Személyek}

Vizsgálatunkban 104 személy vett részt: 52 gyermek, akik életkora 60 és 72 hónap között volt (átlag: 67.2 hónap), illetve 52 felnôtt (életkori tartomány: 18-42 év; átlag: 23.92 év). A felnôtt- és gyermekcsoportot is két egyenlô részre osztottuk, így négy 26 fôs almintát kaptunk. 26 gyermek és 26 felnôtt kapott szinuszhullámú beszédingereket (gyerek szinusz és felnôtt szinusz csoport), mindkét korcsoportból ugyanennyien pedig amplitúdómodulált ingereket (gyerek VOC és felnôtt VOC csoport). A két gyerekcsoport életkori adatai igen hasonlóak voltak (szinuszcsoport: 61-72 hónap, átlag 67.35 hónap; VOC csoport: 60-72 hónap, átlag: 67.08 hónap). Nemek szempontjából mind a négy alminta kiegyenlített volt: 13-13 lány/fiú, illetve nô/férfi vett részt a kísérletben. A felnôtt kísérleti személyek 18. életévüket betöltött középiskolások, egyetemisták, illetve pedagógiai szakszolgálati dolgozók voltak. A tipikus nyelvi fejlôdést a gyerekcsoportban tesztekkel ellenôriztük (lásd alább), a felnôtt csoportban önbevallásra hagyatkoztunk; a személyeknek eszerint nem volt hallási, korábbi nyelvfejlődési problémájuk, illetve olyan beszédhibájuk sem, amit a logopédus képzettségú vizsgálatvezetô észlelt volna. A kutatásban részt vevô gyermekek mindegyikének szüleitôl írásos beleegyezó nyilatkozatot kértünk. A kutatás tervét az ELTE Bárczi Gusztáv Gyógypedagógiai Karának Etikai Bizottsága elôzzetesen jóváhagyta.

\section{Ingerek}

Vizsgálatunkban kétféle módon szintetizált beszédingereket - mondatokat - használtunk: szinuszhullámú, illetve amplitúdómodulált beszédet. ${ }^{5}$ Ehhez egy elôzetesen összeállított mondatlistáról hangfelvételt készítettünk; a mondatokat egy logopédus képzettségú férfi munkatárs mondta mikrofonba. A hangrögzítést a Bárczi Gusztáv Gyógypedagógiai Kar Ecseri úti hallásvizsgáló laborjában, tehát teljesen hangszige-

Egyik ingerként használt mondatunk természetes kiejtésben, valamint szinuszhullámú és amplitúdómodulált változatban is meghallgatható a következó internetes oldalon: http://barczi.elte. hu/content/kutatas.t.1250 
telt körülmények között végeztük. Ehhez egy Audio Technica AT2010-es kondenzátor mikrofont használtuk (Focusrite scarlett 2i4 hangkártyával), amely elé pop filtert helyeztünk a torzítások kiküszöbölésére. A hangrögzítést az Audacity program vezérelte. A nyers felvételek hangerejét a Praat programmal egységesen 70 decibelre (az amplitúdó négyzetes középértéke: 0.0632 Pascal) állítottuk be, és ezen változatból szintetizáltuk a szinuszhullámú és amplitúdómodulált mondatainkat.

A szinuszhullámú és amplitúdómodulált beszédet is e természetes kiejtés alapján készítettük. A szintézist a Praat szoftverre írt programokkal végeztük. ${ }^{6} \mathrm{E}$ programok eredetijét Chris Darwin készítette; ${ }^{7}$ a jelen kutatásban csak kisebb módosításokat végeztünk rajtuk: az amplitúdómodulált beszéd frekvanciasávjait, illetve a szinuszbeszéd formánsainak keverési paramétereit módosítottuk. A szinuszhullámú szintézis az elsố három formánst (F1, F2, F3) helyettesítette egy-egy frekvencia- és amplitúdómodulált szinuszhullámmal, és ezeket adta össze. ${ }^{8}$ Az amplitúdómodulált beszédingereknél hat sávot használtunk, miután a négysávos változat egy gyors elôtesztben túl nehéznek tûnt a gyerekek számára. A hat frekvenciasáv (melyeken belül csak az amplitúdó változott, de az egyes sávoké egymástól függetlenül) a következô volt: 50-300 Hz; 300-600 Hz; 600-1200 Hz, 1200-2400 Hz; 2400-4800 Hz; 4800-8000 Hz. Minden, a vizsgálatban használt ingert .wav formátumban tároltunk.

A felhasznált mondatok listája a Függelékben található. Tíz alapmondatot használtunk, és mindegyiknek volt egy módosított szórendú (de azonos jelentésû), illetve egy jelentés szempontjából módosított változata is. A nyolc, éles próbában szereplő alapmondat két csoportra oszlott. Négy olyan alapmondat volt, melyben az ige argumentumainak felcserélésével (cselekvôváltással) kaptuk meg a szemantikai változatot (ezeket hívtuk „felcserélhetô” vagy $\mathrm{F}$ típusú mondatoknak); a másik négy mondatban az igei csoport megváltoztatásával (tehát új kifejezés bevezetésével) módosítottuk a jelentést (NF típusú mondatok). A szórendi változatoknál a topikot változtattuk meg az alapmondathoz képest. A teljes ingerkészlet tehát 30 mondatból állt; ezek mindegyikébôl szinuszhullámú, illetve amplitúdómodulált változatot is készítettünk. A mondatok hossza 9 és 18 szótag között változott; szerkesztésük fố szempontja az volt, hogy óvodás korú kísérleti személyeink számára jól érthetőek és szórakoztatóak legyenek, ezáltal segítve figyelmük fenntartását a kísérlet során.

6 A Praat hang-, illetve beszédelemzô számítógépes rendszer készítôi Paul Boersma és David Weenink (Phonetic Sciences, University of Amsterdam, Spuistraat 210, 1012VT Amsterdam, Hollandia). A rendszer szabad felhasználású (http://www.fon.hum.uva.nl/praat/).

7 A szinuszhullámú beszédre használt eljárás forrása: http://www.lifesci.sussex.ac.uk/home/Chris_ Darwin/Praatscripts/SWS ; Az amplitúdómodulált beszédszintézisé: http://www.lifesci.sussex.ac.uk/ home/Chris_Darwin/Praatscripts/Shannon.

$8 \quad$ Egy lehetôség a szinuszhullámú beszédingerek nehezítésére, ha csak az alsó egy vagy két formáns szinuszváltozatát használjuk (F1, illetve $\mathrm{F} 1+\mathrm{F} 2)$. A háromformánsos változat jelen vizsgálatban optimális választásnak tûnt a gyerekek és felnôttek teljesítményének összehasonlítására. 


\section{Kisérleti terv}

A beszédészlelési vizsgálatban két gyakorló próba, majd ezt követôen nyolc éles próba szerepelt, próbánként két szintetizált mondattal: egy alapmondattal, és annak egy módosított változatával. Minden éles próbában elôször egy alapmondat szintetizált változatát mutattuk be, és a személy elismételte azt, amit megértett belóle. Amennyiben nem volt tökéletes a mondat elismétlése, bemutattuk a mondatot természetes kiejtésben, és újra annak elismétlését kértük. Végül minden éles próbában egy módosított változatot - vagy a szemantikait, vagy a szórendit - mutattunk be szintetizált formában, és ennek elismétlését kértük. Amennyiben már az alapmondat elsô, szintetizált változatát tökéletesen elismételte a személy, a következô lépésben rögtön a módosított változatot adtuk, és a természetes kiejtést abban a próbában nem mutattuk be. A próbák ilyen felépítésével az volt a célunk, hogy a szinuszhullámú, illetve amplitúdómodulált beszéd észlelésénél tapasztalható „aha” élményt (tehát amikor a természetes kiejtés után újra halljuk a szintetizált változatot, és azt azonnal megértjük) egyfajta teljesítményfeladatba fordítsuk. A megváltozott jelentésú vagy szórendú mondat helyes elismétlése jelezheti azt, hogy a személy a természetes kiejtésből származó emlékein túl az alapmondat megváltozott jellegzetességeit is észleli, tehát egy kismértékú, de azonnali transzferhatás jelenik meg. ${ }^{9}$

Minden személynek a nyolc éles próbából négyben szemantikai (F vagy NF), a másik négyben pedig szórendi változatot adtunk az alapmondat után. Ezen kívül a kapott négy szemantikai változatból mindenkinél kettố $\mathrm{F}$ típusú, kettô pedig NF típusú volt. Minden egyes csoportban (gyerek szinusz; gyerek VOC; felnôtt szinusz; felnôtt VOC) minden személy más és más mondat esetében kapott $\mathrm{F}, \mathrm{NF}$, illetve szórendi változatot, de e három típusba esô változatok száma mindenkinél ugyanannyi volt (2; 2; 4). A nyolc éles próba sorrendjét randomizáltuk; egy csoporton belül mindenki más sorrendben kapta az alapmondatokat. Ugyanakkor mind a négy csoport tagjai az ingerelrendezéseknek ugyanazt a halmazát kapták. Egészében tehát a módosított változatokkal együtt tizenhat mondat jelent meg a nyolc éles próbában, és hat a két gyakorló próbában (mivel itt a szórendi és az NF típusú szemantikai változatot is bemutattuk, mindkét esetben).

\section{Eljárás és eszközök}

Mivel célunk a tipikus nyelvfejlôdésû populáció beszédészlelésének vizsgálata volt, ellenôriztük a tipikus, életkornak megfelelố nyelvi fejlettséget. A gyermekcsoportban ezt két módszeregyüttes használatával végeztük. Minden gyermek résztvevôvel elvégeztük a SZÓL-E logopédiai szürôvizsgálatot (Kas, Lôrik, Bogáth és Mályi, 2012), valamint a

\footnotetext{
Sôt, a szemantikai, illetve szórendi változatok esetében e transzferhatás mértéke különbözhet is. Bár erre vonatkozóan részletes következtetést nem lehet levonni ilyen kis ingerkészlet (négy szemantikai és négy szórendi változat) alapján, amennyiben erre utaló jelet látunk, ez a késôbbiekben alaposabban is megvizsgálható (Pléh és Sinkovics, 2011). Ugyanakkor a szinuszhullámú, illetve amplitúdómodulált mondatok hallgatása során fellépô gyors perceptuális tanulás hatását több más módon is lehet vizsgálni; az eredmények bemutatásánál ezt egy másik elemzési módszerrel is megtesszük.
} 
GOH-GMP teszt öt altesztjét: GMP1 - hallás; GMP2 - mondatazonosítás zajban; GMP3 - szóazonosítás zajban; GMP4 - szúk frekvenciás mondatok azonosítása; GMP5 - gyorsított mondatok azonosítása (Gósy, 1995). A felnốtt csoportban nem végeztünk nyelvi képességfelmérést; önbevallás alapján válogattuk a résztvevôket, akiknek eszerint nem volt hallási, korábbi nyelvfejlôdési problémájuk és a logopédus képzettségú vizsgálatvezetô által észlelhetô beszédhibájuk sem. A gyerekeknél így két ülésben végeztük a vizsgálatot: az elsôben a nyelvi fejlettséget vizsgáltuk, a másodikban pedig a szintetizált beszédingereket mutattuk be. A felnôtt csoportokat egy ülésben vizsgáltuk.

A szinuszhullámú, illetve amplitúdómodulált beszédingereket egyforma eljárással mutattuk be. Az instrukcióban azt mondtuk a gyermek és felnôtt kísérleti személyeknek, hogy szokatlanul hangzó beszédet fognak hallani, mely elsố hallásra nem is hangzik beszédszerúen, de kis gyakorlás után megérthetô. A szinuszhullámú mondatok esetében ezt madárcsicsergéshez, füttyszóhoz, illetve a Csillagok háborúja c. filmból R2D2 beszédéhez hasonlítottuk; az amplitúdómodulált beszédet pedig a szél susogásához. Arra kértük a résztvevôket, hogy bármennyit is értenek meg a hallott beszédból, azt ismételjék meg. A hallott mondat elismétlését a természetes kiejtésû mondatok esetében is kértük. A válaszokat iPaden, Quick Voice programmal rögzítettük. Az ingereket hordozható számítógéprôl, egy Digital HD-838 típusú félig zárt fejhallgatón át mutattuk be, tehát a személyek fejhallgatóval a fejükön a vizsgálatvezetô hangját is értették. Az ingerbemutatás mindig csöndes helyiségben történt. A hangerôt egy Voltcraft SL100 típusú hangnyomásmérôvel 65 dB csúcsintenzitásra állítottuk be.

\section{Az adatok értékelése}

Minden mondat esetében a helyesen felismert szavak, szótagok, illetve magán- és mássalhangzók számát is rögzítettük. Elemzésünk alapja az, hogy a kísérleti személyek az egyes mondatoknak hány százalékát ismerik föl. Az angol nyelvi anyagon, szinuszhullámú, illetve amplitúdómodulált mondatokkal végzett vizsgálatokban általában a sikeresen felismert szavak és a mondat összes szavának arányát használják függố változóként (Rosner és mtsai, 2003; Nittrouer és mtsai, 2009; Nittrouer és Lowenstein, 2010; Lowenstein és mtsai, 2012; Hervais-Adelman és mtsai, 2011). Angol nyelvú ingeranyaggal végzett vizsgálatokban csak olyan esetekben alapozzák az elemzést szótagegységekre, amikor maguk az ingerek is szótagok, és nem szavak vagy mondatok (Nittrouer és Lowenstein, 2009; Hillenbrand és mtsai, 2011). ${ }^{10}$ Mi a felismert szótagok százalékos arányát használtuk; ennek indoklását lásd alább.

10 Egy további módszerben, melyet két év körüli gyerekekkel alkalmaztak, a kutatók egyszerû felszólító mondatokat játszottak le szinusz és VOC változatban (pl. „Nézd a kockát!”), és az ezek hatására előálló nézési idôket mérték (minden felszólítás idején két kép volt jelen, melyek közül az egyiken szerepelt a megnevezett tárgy; Newman és mtsai, 2013). 


\section{EREDMÉNYEK}

\section{A felismerési mutatók összefüggése}

Felmerült bennünk, hogy az angol és a magyar nyelv közti fonológiai különbségek miatt a felismert szótagok százalékos aránya a magyarban jobban értelmezhetô mutató, mint az angol esetében, és valamivel finomabb felbontású is, mint a szavak felismerési aránya. Nem is szükségszerú - noha mondatok esetében igen valószínú -, hogy e két mutató szorosan korreláljon egymással. E kérdés megválaszolására egy elôzetes vizsgálatot végeztünk: a nyolc, éles próbákban használt alapmondatra kiszámoltuk a két mutató (felismert szavak, illetve felismert szótagok százaléka) közötti korrelációt a teljes mintán. A korrelációs együtthatók értéke a nyolc alapmondatra 0.980 és 0.999 között változott. Mivel adataink jórészt nem normális eloszlásúak (lásd alább), a Spearmanféle rangkorrelációkat is kiszámoltuk; ezek értéke 0.976 és 0.999 között volt. Ez tehát arra utal, hogy ingereink esetében teljesen mindegy, hogy a szótagok vagy a szavak felismerési arányát tekintjük alapadatnak. A további elemzésekben a felismert szótagok százalékos arányait használjuk függô változóként. ${ }^{11}$

A személyek nyolc alapmondatból számolt átlagos felismerési értéke a négy csoportból háromban normális volt, a felnoott VOC csoportban a plafonhatásnak köszönhetốen negatív ferdeség volt megfigyelhetô (Shapiro-Wilk próba, $\mathrm{p}<.05$; a ferdeségre: $\mathrm{z}=-2.2275, \mathrm{p}<.05)$. Az egyes mondatok esetében a felismerési arányok eloszlása sehol nem volt normális a szélsôségek ( 0 , illetve 1 közeli értékek) gyakori előfordulása miatt.

\section{Személyek szerinti elemzések}

Adataink elemzésénél elôször a kísérleti személyeket tekintettük individuumnak, és a teljesítményeiket elemeztük.

\section{Átlagos felismerési teljesítmény a nyolc alapmondatra}

Kísérleti személyeink, gyerekek és felnôttek egyaránt, jól teljesítettek mindkét ingertípus felismerésében. Ebben az elsô elemzésben a függô változó a személyek nyolc mondat alapján számolt átlagos teljesítménye volt (1. táblázat).

A felnôttek mindkét ingertípus mellett jobban teljesítettek, mint a gyerekek. Ezt két szempontos független mintás VA segítségével mutattuk meg (2 korcsoport $\mathrm{x} 2$ ingertípus). Mindkét fôhatás szignifikáns volt (korcsoport: $\mathrm{F}(1,100)=138.715, \mathrm{p}<.0001, \eta^{2}$ $=0.581$; ingertípus: $\left.\mathrm{F}(1,100)=11.381, \mathrm{p}<.001, \eta^{2}=0.102\right)$. Utólag t-próbákkal is megvizsgáltuk, hogy az egyes ingertípusokra külön-külön is eltér-e a korcsoportok teljesítménye. Mind az SWS, mind az VOC ingertípusnál a felnôttek szignifikánsan jobban teljesítettek mint a gyerekek (SWS: $\mathrm{df}=47.03, \mathrm{t}=8.47, \mathrm{p}<.001, \mathrm{r}=0.777$; VOC: $\mathrm{df}=$

11 A százalékos értékeket mindenhol 0 és 1 közé skáláztuk, tehát pl. a 0.54-es érték felel meg 54\%-os felismerésnek. 
1. táblázat. A szótagok átlagos felismerési aránya szórásokkal a nyolc mondatra, két csoportban és két ingerfeltétel (SWS, VOC) mellett

\begin{tabular}{l|l|l|l}
\hline \multicolumn{2}{c|}{} & Gyerek & Felnótt \\
\hline \multirow{3}{*}{ SWS } & Átlag & 0.504 & 0.788 \\
\cline { 2 - 4 } & Szórás & 0.135 & 0.104 \\
\hline \multirow{3}{*}{ VOC } & Átlag & 0.558 & 0.919 \\
\cline { 2 - 4 } & Szórás & 0.213 & 0.059 \\
\hline
\end{tabular}

28.86, t = 8.34, p <.001, r = 0.841; Welch-próba). Ezenkívül a gyerekek egyformán teljesítettek a kétféle ingertípusra, a felnôttek viszont a VOC ingertípusra szignifikánsan jobban teljesítettek, mint az SWS-re $(\mathrm{df}=39.622$, $\mathrm{t}=5.58, \mathrm{p}<.001, \mathrm{r}=663$; Welch-próba). Ennek ellenére a varianciaanalízisben az interakció nem volt szignifikáns, vagyis a korral való fejlődés mértéke adataink szerint nem különbözik a két ingertípus között. Ez az elemzés kiterjeszthetô egy harmadik szempontra is, arra, hogy az egyes mondatok mennyire bizonyultak nehéznek a négy csoportban. Erre az elemzés második részében, a mondatok mint individuumok vizsgálatakor térünk vissza.

A nemek közti különbséget ugyancsak a nyolc mondatból számolt átlagos felismerési arány alapján számoltuk. Háromszempontos, független mintás VA (2 nem X 2 életkor X 2 ingertípus) szignifikáns föhatást mutatott az életkorra $\left(\mathrm{p}<.001 ; \mu^{2}=0.586\right)$ és az ingertípusra $\left(\mathrm{p}<.01, \mu^{2}=0.103\right)$ is, nemekre azonban nem. Egyetlen interakció sem volt szignifikáns ebben a vizsgálatban. Ezután a nemek különbségét mind a négy csoportban külön-külön is megvizsgáltuk kétmintás t-próbával, és egyikben sem kaptunk szignifikáns különbséget. Így a további vizsgálatokban a ksz-ek nemét mint független változót nem használtuk.

\section{Perceptuális tanulási hatások a próbák során}

A próbák során megjelenô perceptuális tanulást elôször az alapmondatokon nyújtott teljesítmény segítségével vizsgáltuk. Ehhez minden személy esetében kiszámoltuk az általa kapott utolsó három (6., 7. és 8.), illetve elsố három mondaton mutatott felismerési teljesítmény különbségét (ezt nevezzük a továbbiakban U3-E3 változónak). ${ }^{12} \mathrm{Ez}$ a képzett különbségváltozó mind a négy csoportban normális eloszlású volt. Egymintás t-próbát végezve ezen a változón, a javulást (perceptuális tanulást) a 0-nál szignifikánsan magasabb érték jelenti: ebben az esetben az adott csoport személyei szignifikánsan jobban teljesítettek az utolsó három próbában kapott mondatokra, mint az elsô három próbában kapottakra. Ezt az összefüggést mind a négy csoportban megvizsgáltuk, és azt kaptuk, hogy egyedül a felnôtt SWS csoportban volt szignifikáns a javulás (egymintás t-próba, $\mathrm{t}=3.84, \mathrm{p}<.001, \mathrm{r}=0.609)$. A p érték a Bonferroni-korrekció után

12 Emlékezzünk rá, hogy a mondatok véletlen sorrendje miatt az egyes személyek más-más mondatot kaptak ugyanazon sorszámú próbában. 

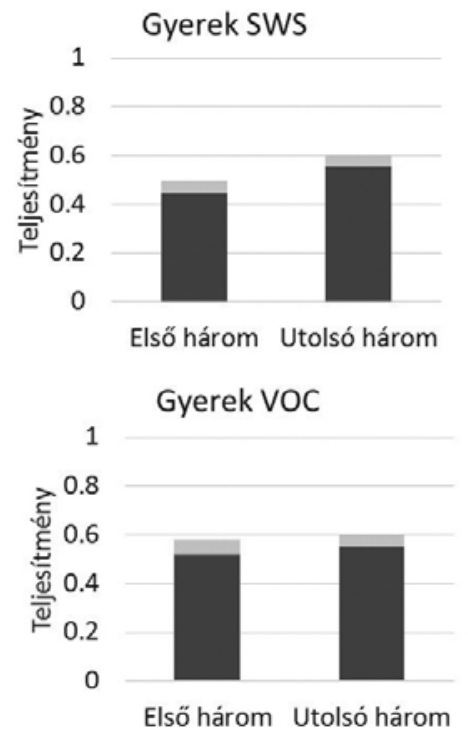
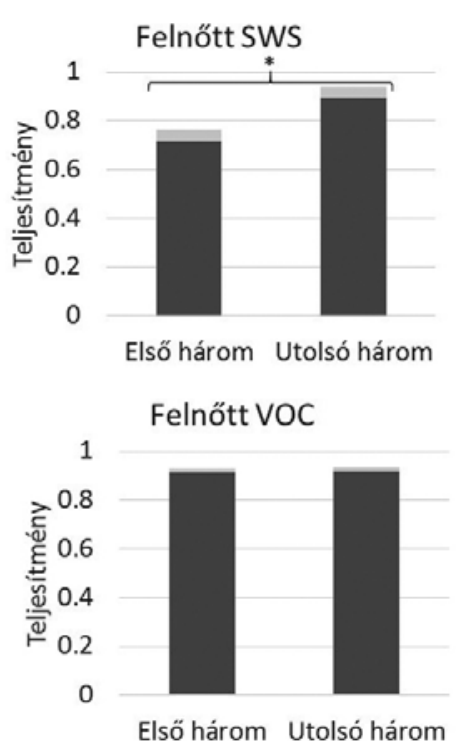

2. ábra. Teljesítményváltozás az elsố három, illetve utolsó három próba átlaga alapján a négy csoportban. A grafikonokon a fekete oszlopok az átlagokat, a világosszürke sávok a standard hibákat mutatják

$\left(\mathrm{p}_{\text {krit }}=0.01 / 4=0.0025\right)$ is szignifikáns maradt. Ezt a teljesítményváltozást mutatja a négy csoportban a 2. ábra.

A 2. ábrán az is látható, hogy a szinuszhullámú alapmondataink a gyerekek számára optimális nehézségúek voltak, és ugyanezek az ingerek még a felnôttek között is megfelelôen diszkrimináltak. A hatsávos amplitúdómodulált ingerek a gyerekek számára szintén megfelelố nehézségúek voltak, a felnôtteknél azonban plafonhatást eredményeztek.

Érdemes egy kicsit tovább vizsgálni a kérdést, hogy vajon a felnốtt SWS csoport, egyedül a négybốl, tényleg mutatta-e jelét a perceptuális tanulásnak a nyolc próba során. Ehhez megvizsgáltunk még további három képzett változót: a nyolcadik, utolsó próbában mutatott teljesítmény és a legelsố próbában mutatott teljesítmény különbségét (U1-E1), az utolsó kettố és elsố kettố különbségét (U2-E2), valamint az utolsó négy és az elsố négy eltérését (U4-E4). E próbák összegzett eredményeit mutatja a 2. táblázat.

A 2. táblázatból látható, hogy a felnốtt SWS csoportban a négy képzett változóból hárommal vizsgálva szignifikáns teljesítményjavulást kaptunk az elsố próbákról az utolsókra, és a negyedik képzett változó sem sokkal maradt el a szignifikáns szinttốl. A másik három csoportban ellenben az elsôfajú hibakorrekció után egyetlen változó sem jelzett szignifikáns teljesítménynövekedést az ülés elejérôl a végére. Ez az eredmény azt jelzi, hogy a jelen módszerrel vizsgálva az fSWS csoportban volt valamiféle teljesítménynövekedés, míg a másik három csoportban nem. 
2. táblázat. A perceptuális tanulásra vonatkozó próbák összegzô táblázata

\begin{tabular}{|l|c|c|c|c|}
\hline & U1-E1 & U2-E2 & U3-E3 & U4-E4 \\
\hline gySWS & NS & $\mathrm{p}<.05$ & NS & NS \\
\hline fSWS & $\mathrm{p}<.01^{*}$ & $\mathrm{p}<.01 *$ & $\mathrm{p}<.001^{*}$ & $\mathrm{p}<.0147$ \\
\hline gyVOC & NS & NS & NS & NS \\
\hline fVOC & NS & NS & NS & NS \\
\hline $\mathrm{p}_{\text {krit }}=0.0125$ & \multicolumn{2}{|c|}{ Wilcoxon } & \multicolumn{2}{c|}{ t-próba } \\
\hline
\end{tabular}

Megjegyzés: Csak a szignifikáns vagy ahhoz közeli értékeket írtuk ki. A négy oszlop a négy képzett változónak felel meg (U1-E1: utolsó próba mínusz elsô próba; U2-E2: utolsó két próba mínusz elsố két próba stb.); a sorok a négy vizsgálati csoportnak. A felnôtt SWS csoportban a négy változóból három szignifikáns teljesítményjavulást jelzett, egy pedig nem szignifikáns, de ahhoz közeli értéket adott. A másik három csoportban Bonferroni-korrekció után egyik változó sem jelzett szignifikáns javulást. A négy változó közül a normális eloszlásúakat t-próbával, az attól eltérôket Wilcoxon-próbával hasonlítottuk össze

Felmerül a kérdés, hogy mi okozhatta ezt a mintázatot. A 2. ábra jobb alsó grafikonján jól látható a felnôtt VOC csoportban megjelenô plafonhatás; e csoport tagjai már az elsố próbákban is majdnem tökéletesen teljesítettek, így az adott feltételek között nem tudtak további javulást mutatni az ülés végére. A bal oldali két grafikonon ellenben jól látszik, hogy a gyerekeknél nem volt plafonhatás, ennek ellenére mégsem javultak a viszonylag rövid kísérleti ülés alatt. További vizsgálatra érdemes kérdés, hogy az óvodás korú gyerekek kevésbé javulnak-e egy egyszeri kísérlet során a szintetizált mondatok felismerésében, mint a felnôttek; vagyis a gyors perceptuális tanulásban kevésbé hatékonyak-e, mint a felnốttek, hasonlóan a már említett Mooney-képekkel, tehát vizuális modalitásban végzett kevés létezô vizsgálatok eredményéhez (lásd fönt). Valamivel több próbából álló ülésekkel, és kicsit nehezebb (pl. hatsávos helyett négysávos) amplitúdómodulált ingerekkel ezt a hipotézist tovább lehet vizsgálni. A nehezebb VOC típusú ingerek várhatóan elmossák a felnôtteknél meglévô plafonhatást, míg a több próbát tartalmazó kísérletek kifejezettebbé tehetik a perceptuális tanulási hatást.

Mivel kiderült, hogy mondataink között viszonylag jelentôs nehézségi különbségek vannak, és e különbségek összefüggenek a szintézis típusával is (lásd alább), felmerült a kérdés, hogy a perceptuális tanulással kapcsolatos eredményünket mennyire befolyásolhatták ezek a nehézségi különbségek. Lehet-e a perceptuális tanulásnak tûnô hatás valójában mútermék? Lehetséges-e például, hogy azok a személyek mutattak „teljesítménynövekedést”, akik az elsố próbákban nehezebb, míg az utolsókban könynyebb mondatokat kaptak ${ }^{13}$ Ennek tisztázására a következô elemzést végeztük el. Elôször kiszámoltuk mind a nyolc alapmondatra és mind a négy csoportban a csoportra jellemzô átlagos teljesítményt. Ezt egyfajta nehézségi mutatónak tekintettük: minél alacsonyabb volt az átlagos teljesítmény, annál nehezebb volt az adott mondat az adott csoport tagjainak. Ezután minden személyre az U3-E3 változó mellé (amely tehát a

13 Megjegyezzük, hogy ez a jelenség nem okozhatott különbségeket a csoportok között a (látszólagos) perceptuális tanulásban, mert, mint föntebb leírtuk, mind a négy csoport tagjai ugyanabban a 26 pszeudo-random sorrendben kapták az ingereket. 
személy saját teljesítményváltozását jellemzi) kiszámoltuk a megfelelố nehézségi indexet is: adott személy által az utolsó három próbában kapott mondatok nehézségeinek összege, mínusz az elsố három mondat nehézségösszege $\left(\mathrm{U}_{\text {csop }} 3-\mathrm{E}_{\text {csop }} 3\right)$. Ezután mind a négy csoportban kiszámoltuk a korrelációt és a regressziós egyenest is az U3-E3, illetve az $\mathrm{U}_{\text {csop }} 3-\mathrm{E}_{\text {csop }} 3$ változók között (3. ábra). Az ábrán látható, hogy mind a négy csoportban azok teljesítménye javult az ülés elejérôl a végére, akik az elején nehezebb, a végén pedig könnyebb mondatokat kaptak; ezt mutatja a mindegyik csoportban szignifikáns korreláció. A felnốtt SWS csoportban azonban e tényezôtôl függetlenül is javult a teljesítmény az ülés elejérôl a végére; ezt mutatja, hogy ebben a csoportban a legmagasabb a b érték (a regressziós egyenes függóleges tengellyel való metszéspontja), és ennek megfelelốen az U3-E3 változó átlaga egyedül ebben a csoportban szignifikánsan nagyobb nullánál (lásd 2. táblázat). $\mathrm{Az} \mathrm{U}_{\text {csop }} 3-\mathrm{E}_{\text {csop }} 3$ változó átlaga egyik csoportban (így a felnốtt SWS-ben) sem tért el szignifikánsan a nullától. ${ }^{14}$ Összefoglalva, tehát ez az elemzés azt mutatta meg, hogy a kísérleti ülés során megfigyelhetô teljesítményváltozásért egyrészt a személyek által kapott mondatok nehézsége (ennek a próbák során megjelenố változása) a felelôs, másrészt ettôl függetlenül kimutatható egy viszonylag gyors perceptuális tanulásként értelmezhetố folyamat is, de csak a felnốtt SWS csoportban. További kutatásra érdemes kérdés, hogy vajon a felnôtt VOC csoportban is megfigyelhetố-e ugyanez a hatás, amennyiben az ingerek nem túl könnyủek a személyek számára (azaz van hová javulniuk a kísérleti ülés elejérôl a végére).

Kiegészítố elemzésként elvégeztünk egy-egy varianciaanalízist ( 2 ingertípus $\times 2$ életkor) az U3-E3, illetve az $\mathrm{U}_{\text {csop }} 3$ - $\mathrm{E}_{\text {csop }} 3$ változókra is. Utóbbi esetben, tehát a nehézségek változásánál, semmilyen szignifikáns hatást nem találtunk. Ez várható is volt, hiszen mind a négy csoportban a mondatoknak ugyanazt a 26 permutációját adtuk. ${ }^{15} \mathrm{Az}$ U3-E3 változó varianciaanalízisében inger szerinti főhatást kaptunk: az SWS ingerekre magasabb volt a teljesítményváltozás értéke, mint a VOC változatokra $\left(\mathrm{p}<0.02 ; \eta^{2}=\right.$ 0.058). A kor szerinti főhatás nem szignifikáns (az ülés elejérốl a végére történt teljesítményváltozásban nem volt megfigyelhetố egységes kor szerinti tendencia). Az interakció szintén nem volt szignifikáns. Ezt tovább elemezve azonban csak a felnôtt SWS és felnốtt VOC csoportok értékei különböztek szignifikánsan ( $\mathrm{df}=34.5 ; \mathrm{t}=3.43 ; \mathrm{p}<.002$, $\mathrm{r}=0.50$, Welch-próba)), a gyerek SWS, illetve gyerek VOC csoportok különbsége nem volt szignifikáns. Ez megfelel annak a már bemutatott eredményünknek, hogy egyedül a felnôtt SWS csoportban volt az U3-E3 érték szignifikánsan nagyobb nullánál.

14 Az ábrán a meredekségek különbségéért jórészt az U3-E3 változó varianciájának csoportközi különbségei felelôsek. Míg az $\mathrm{U}_{\text {csop }} 3-\mathrm{E}_{\text {csop }} 3$ változó varianciája a négy csoportban 0.25 és 0.36 között változott, az U3-E3 változó varianciája a gyerek SWS csoportban 0.94, míg a felnôtt VOC csoportban 0.15 volt (ez az alacsony érték pedig a plafonhatás eredménye lehet).

15 Bár az egyes személyek eltértek abban, hogy az elsố három, illetve utolsó három próbában mely mondatokat kapták, s ennek megfelelốen az egyes személyekhez tartozó $\mathrm{U}_{\text {csop }} 3$-E $\mathrm{esop}_{3} 3$ értékek is különböztek, a csoportok között ebben az indexben lényeges eltérést nem vártunk és nem is kaptunk. (Valamennyi eltérés adódhatott volna, mert egy adott mondat nehézségi indexe - átlagos felismerése - eltérhetett a négy csoportban.) 
(a) Gyerek SWS

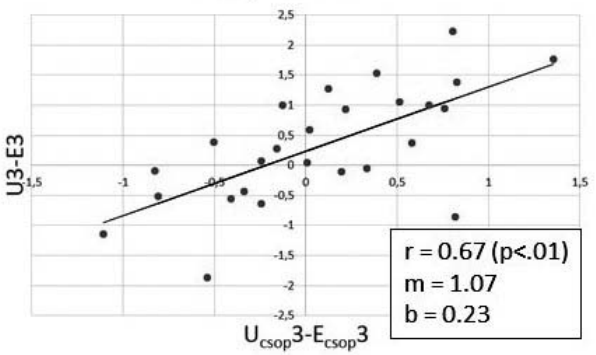

(c) Gyerek VOC

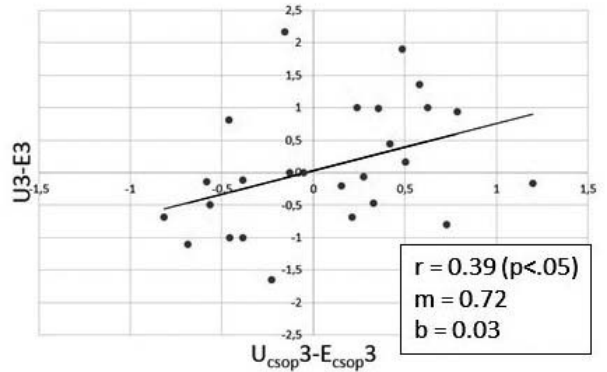

(b) Felnőtt SWS

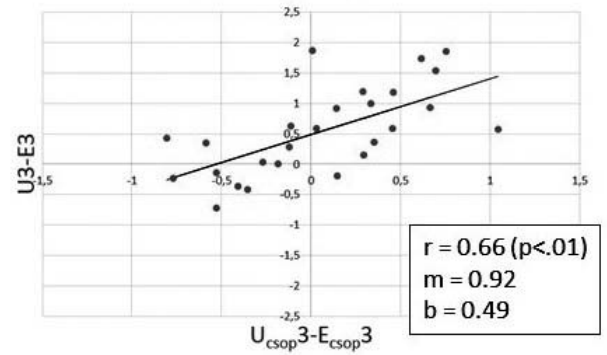

(d) Felnőtt VOC

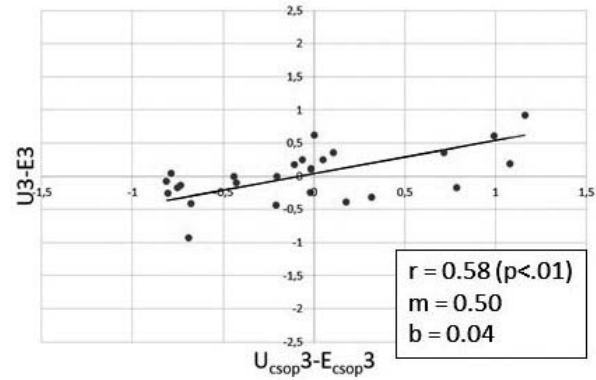

3. ábra. Az ingernehézség és a teljesítmény változása közötti összefüggés a négy csoportban A szövegdobozokban a korrelációs együttható (r), a regressziós egyenes meredeksége (m) és

függốleges tengellyel való metszéspontja (b) látható. További magyarázat a szövegben

\section{Mondatok szerinti elemzések}

A négy csoport teljesítményei a nyolc alapmondaton

Mint korábban említettük (lásd A felismerési mutatók összefüggése c. részben), az egyes mondatok személyenkénti teljesítménymutatói nem normális eloszlásúak, de a nyolc mondaton nyújtott átlagos teljesítmény a négy csoportból háromban igen (a kivétel a felnôtt VOC csoport, és a normalitássértés vélhetô oka a plafonhatás). Ugyanakkor az egyes mondatok nem voltak egyformán nehezek a személyeink számára, sốt, ezek a nehézségi profilok különböztek a csoportok között (lásd 4. ábra). E mintázat elemzésére a legkézenfekvőbb egy háromszempontos VA (2 életkor X 2 ingertípus X 8 alapmondat; utóbbi ismétléses faktor) elvégzése. Ennek értelmezése azonban nem egyszerú, mert a normalitási feltétel mellett az ismétléses faktorra vonatkozó szfericitási és a csoportközi faktorokra vonatkozó szóráshomogenitási feltétel sem teljesült az adatainkra (a Maulchy-próba és a Levene-próba egyaránt szignifikáns volt). Ezt az elemzést mindazonáltal elvégeztük. ${ }^{16}$

16 Az eredményeket a következô módon látjuk értelmezhetônek. A vegyes VA normalitás sértésére elfogadhatóan robusztus (Vargha, 2000, 421); a szfericitássértéssel szemben a Huynh-Feldt, illetve Greenhouse-Geisser-eljárásokat használtuk. A csoportközi különbségekre vonatkozó robusztus eljárást ugyan nem számoltuk ki, de a csoportközi faktorokra lényegében ugyanazt kaptuk, mint az Átlagos felismerési teljesítmény a nyolc alapmondatra címú részben leírt két szempontos (2 kor X 2 ingertípus) varianciaanalízisben. Az elsôfajú hibák valószínúségei pedig elég alacsonyak ahhoz, hogy viszonylag biztosak lehessünk a kapott hatások meglétében (lásd a fôszöveget). 


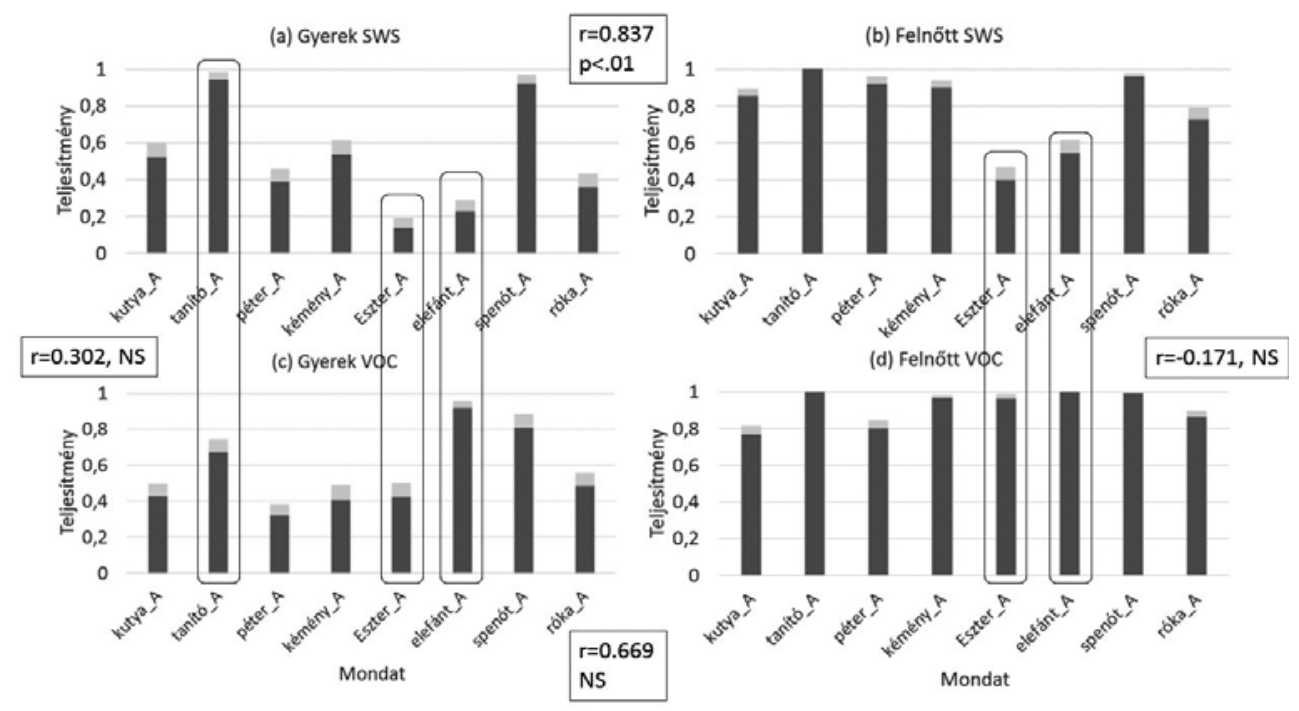

4. ábra. Az egyes alapmondatokra kapott nehézségek (átlagos felismerési teljesítmények) a négy csoportban. A kerettel jelölt mondatok azok, amelyek esetében a leglátványosabb volt a különbség az SWS és VOC változat felismerése között, adott korcsoporton belül. Ezt az öt esetet kétmintás t-próbával is megvizsgáltuk (a többit nem), és Bonferroni-korrekció után ( $\mathrm{p}_{\text {krit }}$ $=0.05 / 5=0.01$ ) valamennyi szignifikáns volt. Az ábrán látható korrelációs együtthatók a megfelelố két csoport teljesítményprofilja közötti összefüggést mutatják

Az ingertípus szerinti foohatás szignifikáns volt $\left(\mathrm{F}(1,100)=11.381, \mathrm{p}<0.01, \eta^{2}=0.102\right)$, mert a VOC feltétel mellett jobban teljesítettek a személyek, mint SWS ingerekre (lásd 1. táblázat). A kor szerinti fơhhatás szintén szignifikáns volt $\left(\mathrm{F}(1,100)=138.715, \mathrm{p}<10^{-15}\right.$, $\left.\eta^{2}=0.58\right)$, mert a felnốttek jobban teljesítettek a gyerekeknél. Ezek az eredmények egybevágnak az Átlagos felismerési teljesítmény a nyolc alapmondatra címú részben bemutatott elemzéssel. A két csoportközi faktor közti interakció nem volt szignifikáns. Az ismétléses faktor szerinti fơhatás is szignifikáns volt, azaz az egyes mondatok nem voltak egyforma nehezek $\left(\mathrm{F}(7,700)=34.040, \mathrm{p}<10^{-15}, \eta^{2}=0.254\right)$. A mondatnehézségi profilok eltérnek az SWS, illetve VOC csoportban (gyerekek és felnôttek együtt; $\mathrm{F}(7,700)=26.57$, $\mathrm{p}<$ $\left.10^{-15}, \eta^{2}=0.21\right)$, és a korcsoportok között is $\left(\mathrm{F}(7,700)=7.38, \mathrm{p}<10^{-7}, \eta^{2}=0.069\right)$. A hármas interakció is szignifikáns volt, vagyis az életkor szerinti profilváltozás eltért a két ingertípus mellett $\left(\mathrm{F}(7,700)=3.02, \mathrm{p}<.01, \eta^{2}=0.019\right)$.

Kicsit másképpen is megvilágíthatjuk a számunkra releváns összefüggéseket. A gyerek SWS és a felnôtt SWS csoport tagjai nagyjából ugyanazokat a mondatokat ismerték fel könnyebben, illetve nehezebben $(\mathrm{r}=0.837$, $\mathrm{p}<0.01$; lásd 4. ábra). Hasonlót láthatunk a gyerek VOC és a felnôtt VOC csoportok viszonyában is, bár utóbbi esetben a korreláció csak közelítóleg volt szignifikáns $(\mathrm{p}<0.1)$. Az alacsonyabb korrelációnak két oka lehet, az egyik a felnôtt VOC csoportban megfigyelhetô plafonhatás, a másik pedig az alacsony szabadságfok $(\mathrm{df}=6)$. Ugyanakkor sem a teljes gyerekcsoport két, ingertípus szerinti alcsoportjára, sem a két felnôtt alcsoportra nem volt szignifikáns a korreláció $(r=0.302$, illetve $r=-0.171)$. Úgy tûnik tehát, hogy a szintézis típusa 
az elsôdlegesen meghatározó tényezô a mondatok egymáshoz viszonyított nehézsége szempontjából, és nem az életkor. Szorosabb ugyanis az összefüggés a szintézis típusa szerint, mint korcsoportok szerint. Ez a megfigyelés arra is utal, hogy mondataink nehézségére a jelentéstôl független, akusztikai tulajdonságok, illetve ezek fonológiai megfeleltetése egyértelmúen hatással volt. Más kérdés, hogy a gyerek-felnôtt teljesítménykülönbségre mely tényezốk voltak elsôsorban hatással: a jobb beszédészlelés vagy a nagyobb szókincs, esetleg mindkettô. E kérdés eldöntéséhez további vizsgálatokra van szükség.

\section{Teljesitmény a módosított változatokon}

Mondataink módosított változataiból az elvártnál sokkal kevesebb eredmény származott, és ennek oka az általános plafonhatás volt ezeken a mondatokon (5. ábra).

Minden csoport szignifikánsan jobban teljesített a módosított változatokon, mint az alapmondatokon (gyerek SWS: $\mathrm{t}=10.98, \mathrm{p}<.001, \mathrm{r}=0.91$; felnótt SWS: $\mathrm{t}=9.42$, $\mathrm{p}<.001, \mathrm{r}=0.883$; gyerek VOC: $\mathrm{t}=9.53, \mathrm{p}<.001, \mathrm{r}=0.886$; felnôtt VOC: $\mathrm{t}=6.85$, $\mathrm{p}<.001, \mathrm{r}=0.808)$. A további tendenciák megvilágításához kiszámoltuk minden személyre a módosított mondatokon produkált átlagos teljesítmény és az alapmondatokon adott átlagos teljesítmény különbségét. Mindenki jobban teljesített a módosított változatokon, mint az alapmondatokon, ezért ez az érték (nevezzük javulási mutatónak) mindenkinél pozitív volt. A javulási mutatón két szempontos (2 kor x 2 ingertípus) varianciaanalízist végeztünk. Itt az életkor szerinti fóhatás szignifikáns volt $(\mathrm{F}(1,100)=66.545$, $\left.\mathrm{p}<10^{-11}, \eta^{2}=0.4\right)$. Ez az eredmény azonban a plafonhatásból eredố artefaktumnak tûnik. A már az alapmondatokon is jobban teljesítô felnốttek kisebbet tudtak javulni a

(a) Gyerek SWS

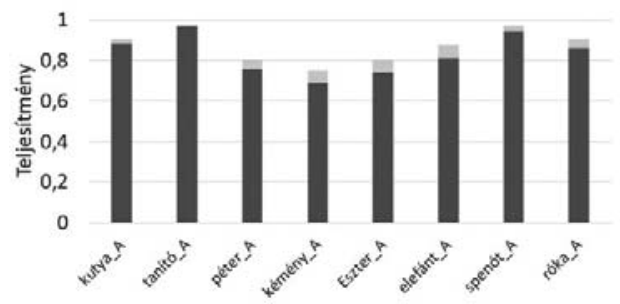

(c) Gyerek VOC

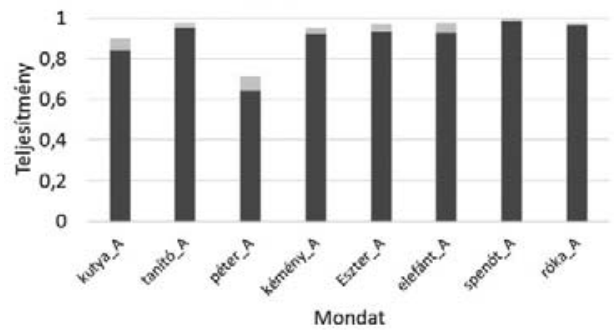

(b) Felnött SWS

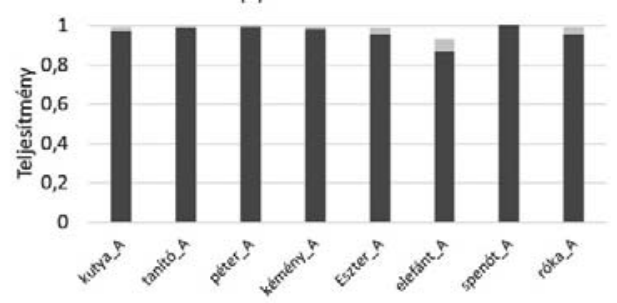

(d) Felnőtt voc

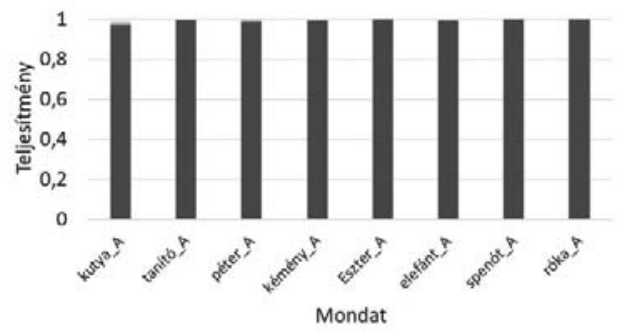

5. ábra. Teljesítmény a mondatok módosított változatán. Különösen a felnôtt csoportokban látható a plafonhatás, de a gyerekcsoportok is lényegesen jobban teljesítettek, mint az elsố bemutatásnál 
módosított változatokon, mint az alapmondatokon gyengébb teljesítményt nyújtó gyerekek, ezért a gyerekek javulási mutatója volt szignifikánsan magasabb a felnôttekénél. Szintén a plafonhatásból eredhet a szignifikáns interakció is $(\mathrm{F}(1,100)=4.948, \mathrm{p}<.03$, $\left.\eta^{2}=0.047\right)$ : míg gyerekeknél SWS, illetve VOC ingerekre nem különbözött a javulási mutató értéke, addig felnôttek esetén SWS ingerekre nagyobb volt, mint VOC ingerekre. Itt is a 4. ábra két jobb oldali grafikonja segít az értelmezésben. A felnôtt VOC csoportban megfigyelhetô a plafonhatás, a felnôtt SWS csoportban nem vagy sokkal kevésbé, ezért az SWS ingerek esetében biztosak lehetünk abban, hogy a korcsoportok közti teljesítményemelkedésnek volt elég tere.

Összefoglalva tehát, a javulási mutató e vizsgálatából egyetlen elméleti szempontból érdekes következtetést vonhatunk le. A személyek szubjektív, „aha” élménye azt jelzi, hogy a természetes kiejtés meghallgatása után ugyanazt a mondatot a megfelelôen szintetizált változatban már tökéletesen megértik. Sôt, úgy tûnik, hogy az eredeti mondat módosított változatát is tökéletesen vagy közel tökéletesen értik szintetizált formában. A módosított változatokon tapasztalt igen magas teljesítmények miatt a szemantikai, illetve szórendi módosított változatok közti teljesítménykülönbségeket nem vizsgáltuk meg.

\section{Az elsố fönévi csoport felismerésének hatása a mondat többi részének felismerésére}

Ezt a vizsgálatot azért végeztük el, mert választ kerestünk arra, hogy mi okozhatja az egyes mondatok közötti felismerési, nehézségbeli különbségeket. Egyrészt azt láttuk, hogy az ingertípus igen erôs hatást gyakorolt az egyes mondatok felismerésére, és ez a hatás jóval erôsebb volt az életkori hatásnál (4. ábra). Kicsit pontosabban úgy fogalmazhatunk, hogy az életkor hatása a teljesítményre nem volt mondatspecifikus, ellenben a szintézis típusa mondatspecifikus hatást gyakorolt a teljesítményre. Ezzel párhuzamosan egy másik hatás is megfigyelhetố a felismerésben, nevezetesen hogy a mondatok elsố fơnévi csoportjának felismerése igen magasan korrelált az adott mondat maradék részének felismerésével. E hatás mögött vélhetôleg a szemantikai restauráció húzódhat meg. Egy konkrét példa erre a következô. Az „Eszter biciklit szeretne születésnapjára” mondat SWS változata a legnehezebb ingerünknek bizonyult. Itt a személyek (gyerekek és felnôttek is) gyakran „egyszer”-nek értették az elsô szót. Ez az értelmezés nyilván igencsak félreviszi a mondat többi részének dekódolását azáltal, hogy a mondat további tényleges szavainak feltételes valószínúségeit alaposan lecsökkenti. Bár előfordult olyan személy, aki az „Egyszer biciklit szeretne születésnapjára” mondattal válaszolt, a személyek többsége inkább értelmezési nehézséggel találta szemben magát, amit a töredékes válaszok nagyobb gyakorisága jelzett ennél a mondatnál. Egy ettôl kissé különbözó eset volt az „Az elefánt elbújt a fa mögé” mondat, itt ugyanis a személyek egy része láthatóan azon csodálkozott, hogy hogy tud egy elefánt elbújni egy fa mögé, s ezért találhatták ezt a mondatot implauzibilis megoldásnak. Ennél a mondatnál tehát - legalábbis egyes személyeknél-szemantikai tényezó is nehezíthette a felismerést. Megjegyzendô ugyanakkor, hogy csoportszinten a szintézis típusa is meghatározó tényezőnek tûnt az „elefántos” mondat felismerésében. E mondat ugyanis szinuszhullámú változatban nehezebb volt, mint amplitúdómoduláltban, és ezt a különbséget gyerekeknél, illetve felnôtteknél egyaránt megtaláltuk (4. ábra). 
Ennél a mondatnál tehát egészében az lehetett a helyzet, hogy a hatsávos VOC változat könnyú érthetôsége nagyjából minden szemantikai, értelmezési kétséget kizárt, így e feltétel mellett a gyerekek közel tökéletes, a felnôttek pedig kivétel nélkül tökéletes (100\%-os) teljesítményt mutattak. A szinuszhullámú változat fonológiai dekódolhatósága viszont rosszabb volt, így itt tere nyílhatott a tûnôdésnek, hogy mennyire lehet a hallott mondat értelmezése plauzibilis.

Az összes mondat alapján az is megfigyelhetô volt, hogy a mondatok elsô fônévi csoportjának sikeres felismerése igen magasan korrelált az adott mondat többi részének felismerésével. A nyolc alapmondatra a négy csoportban a következô korrelációkat kaptuk (3. táblázat).

3. táblázat. Korrelációk a nyolc alapmondat elsố fốnévi csoportjának, illetve az azt követô részének felismerése között

\begin{tabular}{l|c|c}
\hline Csoport & $\mathbf{r}$ & $\mathbf{p}(\mathbf{d f}=\mathbf{6})$ \\
\hline gyerek SWS & 0.959 & $\mathrm{p}<.01$ \\
\hline felnőtt SWS & 0.836 & $\mathrm{p}<.01$ \\
\hline gyerek VOC & 0.765 & $\mathrm{p}<.05$ \\
\hline felnőtt VOC & 0.749 & $\mathrm{p}<.05$ \\
\hline
\end{tabular}

További magyarázat a szövegben.

A 3. táblázat értelmezését segítendő közöljük a gyerek SWS csoportban a nyolc alapmondatra vonatkozó részletes adatokat is (4. táblázat).

Ezen adatok alapján egy kétlépcsôs modellt vázolhatunk fel a mondatok felismerésére vonatkozóan. Az elsố fơnévi csoport felismerése, értelmezése során a legkisebb a lexikai restaurációs hatások tere, hiszen ekkor még a mondat elején járunk, a szövegkörnyezetből nem lehet következtetni az elhangzó jelek jelentésére. Ekkor a felismerésre az lehet döntô hatással, hogy a kétféle beszédszintézis eredményeként elôálló ingerek milyen mértékben segítik a megfelelố fonológiai kategóriák aktiválását. Feltételezhetô például, hogy a szinuszhullámú beszéd a magánhangzók felismerését na-

4. táblázat. A gyerek SWS csoport adatai a nyolc alapmondat elsố fônévi csoportjának, illetve további részének felismerésérôl

\begin{tabular}{l|l|l|l}
\hline Eleje & Felismert\% & Vége & Felismert\% \\
\hline A harapós kutya & 0.545 & elkergette a medvét a kertból & 0.508 \\
\hline A tanítónéni & 0.962 & mindenkinek adott egy kis ajándékot & 0.936 \\
\hline Péter & 0.308 & vendégül látta barátait a nagy sátorban & 0.359 \\
\hline A kéményseprố & 0.446 & kölcsönadta a kabátját a kisfiúnak. & 0.571 \\
\hline Eszter & 0.077 & biciklit szeretne születésnapjára & 0.144 \\
\hline Az elefánt & 0.058 & elbújt a fa mögé & 0.340 \\
\hline Minden gyerek & 0.942 & megette a spenótot & 0.912 \\
\hline A ravasz róka & 0.223 & megszerezte a finom sajtot & 0.436 \\
\hline
\end{tabular}

A korrelációs együttható a két számoszlop között ebben az esetben 0.959 . 
gyobb mértékben támogatja, mint a mássalhangzókét (Remez és Rubin, 1990; Remez és mtsai, 1994; Hillenbrand és mtsai, 2011). Ez azért lehet így, mert a frekvenciamodulált szinuszhullámok pontosan követik a magánhangzók formánsait, ellenben a mássalhangzók zörejkomponenseinek megfelelố frekvenciainformáció hiányzik belólük. Az amplitúdómodulált beszédingerek viszont elsôsorban a zöngétlen mássalhangzók zörejkomponenseit ôrzik meg, a formánsokat nem. Egészében tehát a felismerés szintézisfüggôségét (az SWS és VOC közti különbséget) ez a tényezô okozhatja, de, mivel mondatokról van szó, a következô szinten lexikai restaurációs hatások is jelentôs szerepet játszanak, és ezek erôsebben érvényesülnek mondataink predikátum tagjában, mint a szubjektumot leíró elsô fơnévi csoportban. A sikerrel felismert elsô fơnévi csoport pedig jó alapot ad a szemantikai restaurációra, miközben a személyek a mondat második részét hallgatják.

\section{ÖSSZEFOGLALÁS ÉS MEGVITATÁS}

Vizsgálatunkból a következô eredményeket érdemes kiemelni. Gyerekek és felnôttek egyaránt jól teljesítettek a szinuszhullámú, illetve amplitúdómodulált mondatok megértésében. Az amplitúdómodulált ingerek felnôttek számára könnyebbnek bizonyultak a szinuszhullámúaknál; gyerekeknél a kétféle ingertípus egyformán nehéz volt. A felnôttek mindkét ingertípusban a gyerekeknél jobban teljesítettek; a nemek között nem találtunk különbséget. Adatainkat összehasonlítva Nittrouer és munkatásai (Nittrouer és Lowenstein, 2010; Lowenstein és mtsai, 2012) eredményeivel, nem találunk teljes összhangot. A két nyelv közötti összehasonlítást segíti az 5. táblázat.

A táblázat alapján a következó megfigyeléseket tehetjük.

(1) A szinuszhullámú ingerek esetén az angol nyelvú vizsgálatban kapott teljesítmény magasabb az általunk megfigyeltnél, az amplitúdómoduláltak esetén ellenben alacsonyabb. Ez a kettós viszony attól függetlenül fennáll, hogy a saját adatainkból az átlagokat a 8 alapmondat avagy mind a 16 tesztmondat alapján számoljuk. Szinuszhullámú ingerek esetén felnôtteknél és 7 éveseknél is olyan magas szinten van az angol személyek teljesítménye, amit mi a saját adatainkban plafonhatásnak minôsítettünk (a felnôtt VOC csoportban). Az,

5. táblázat. Felismerési arányok Nittrouer és Lowenstein (2010) adatai, illetve a jelen vizsgálat alapján

\begin{tabular}{c|c|c|c|c|c|c|c}
\hline \multirow{2}{*}{} & \multicolumn{2}{|c|}{ Nittrouer és Lowenstein, 2010 } & \multicolumn{2}{c|}{8 alapmondat } & \multicolumn{2}{c}{16 tesztmondat } \\
\cline { 2 - 8 } & Felnőttek & $\mathbf{7}$ évesek & 5 évesek & Felnóttek & 5-6 évesek & Felnőttek & 5-6 évesek \\
\hline & 0.984 & 0.919 & 0.863 & 0.788 & 0.504 & 0.876 & 0.668 \\
SWS & $(0.014)$ & $(0.03)$ & $(0.061)$ & $(0.104)$ & $(0.135)$ & $(0,120)$ & $(0.203)$ \\
\hline & 0.795 & 0.439 & 0.307 & 0.919 & 0.558 & 0.956 & 0.727 \\
VOC & $(0.083)$ & $(0.166)$ & $(0.179)$ & $(0.059)$ & $(0.213)$ & $(0.057)$ & $(0.238)$ \\
\hline
\end{tabular}

A cellákban a felsố értékek átlagos felismerési arányt fejeznek ki, alattuk zárójelben a szórások. Nittrouer és Lowenstein az átlagosan felismert szavak számát közlik, ingertípusonként 6 gyakorló és 24 tesztmondat alapján. A saját adataink a felismert szótagok arányainak átlagai a 8 alapmondat, illetve mind a 16 tesztmondat alapján (tehát az alapmondatok módosított párját is beszámítva) 
hogy a VOC mondatokon a mi személyeink jobban teljesítettek az angolok alanyoknál, annak tulajdonítható, hogy míg Nittrouerék négysávos, mi hatsávos amplitúdómodulációt használtunk, és utóbbi megkönnyíti a beszédészlelést. A szinuszhullámú ingereken megfigyelhetố ellentétes irányú különbség már nem értelmezhetô ilyen könnyen, de elképzelhetô, hogy az angol nyelvú vizsgálatban adott valamivel több gyakorlási lehetôség az egyik magyarázó tényezô. Nittrouer és Lowenstein vizsgálatában a személyek ingertípusoknént 6 gyakorló és 24 éles próbát kaptak. Emellett minden személy szinuszhulllámú és amplitúdómodulált kísérleti blokkban is részt vett. A jelen vizsgálatban a szintézis típusa csoportközi változó volt, így minden személy egyetlen szintézistípusban összesen 20 szintetizált mondatot hallgatott meg. Nittrouerék személyeinek tehát egy ingertípuson belül is másfélszer annyi gyakorlásra volt lehetôségük, mint a mi vizsgálatunkban. A mi ingereink között az alapmondatok és módosított párjaik meglehetôsen hasonlóak voltak egymáshoz. Ezért érdemesebb a 8 független alapmondaton alapuló átlagot használni az összehasonlításhoz. Nittrouerék vizsgálatában egy ingertípuson belül minden mondat független volt egymástól: nem voltak egymás transzformációi. Mindazonáltal a szinuszhullámú ingerekben megfigyelt nyelvközi teljesítménykülönbséget nem tekinthetjük tökéletesen megmagyarázottnak, itt további vizsgálatokra van szükség.

(2) Az angol nyelvú vizsgálatban minden korcsoportban jobban teljesítettek a személyek az SWS ingereken, mint a VOC ingereken. A mi adataink fordított viszonyt mutatnak. E fordított viszony valószínú oka ismét az, hogy Nittrouerék négysávos, míg mi hatsávos amplitúdómodulációt használtunk. Mi a gyerekekkel végzett gyors elôvizsgálatunk tapasztalatai alapján döntöttünk a hatsávos szintézis mellett: az elsô négy megvizsgált óvodás számára a négysávos ingerek frusztrálóan nehéznek túntek, igen keveset értettek meg belôlük.

A Nittrouerék és saját adataink közti ellentmondás viszonylag egyszerúen feloldható, legalábbis egy kézenfekvő hipotézis segítségével. A 6. ábrát és az 5. táblázatot összevetve látható, hogy ha a VOC teljesítmény mindkét korcsoportunkban arányosan alacsonyabb lett volna, akkor Nittrouerék eredményeihez hasonló mintázat állna elô: mindkét korcsoport jobban teljesít az SWS mondatokra (az ábrán a hipotetikus VOC vonal az SWS alatt fut), de a gyerekeknél az SWS ingerek elônye nagyobb a (hipotetikus) VOC ingerekhez képest, mint felnôtteknél. Lehetséges, hogy a négysávos VOC ingerekhez ragaszkodva ehhez hasonló eredményeket kaptunk volna; ezt további vizsgálatokkal kell tisztázni.

Egészében tehát nyilvánvaló, hogy az elszegényített beszédingerek észlelése jelentôs mértékben fejlődik hatéves kortól felnôttkorig.

A rövid távú perceptuális tanulási jelenségekkel kapcsolatban a következóket figyelhetjük meg. A bevezetôben említett Mooney-képekkel összevetve az ezekkel kapcsolatban megfigyelhetô azonnali perceptuális tanulás a szintetizált beszédingereknél is megjelent, ráadásul mindkét korcsoportban; ezt a módosított változatokon tapasztalt plafonhatás igazolja. Fontos kiemelni, hogy ez a hatás egyedi ingerekre vonatkozik, és nem tartalmaz utalást más, hasonló ingerekre való tanulási transzferre: egy inger elszegényített változatát elôször nem ismerjük fel, majd az eredeti, részletgazdag változat észlelése után azonnal felismerjük, és ezt egy jellegzetes „aha” élmény is kíséri. Itt tehát lényeges az ugrásszerú javulás. Ugyanakkor vannak jelei egy, a próbák során fokozato- 


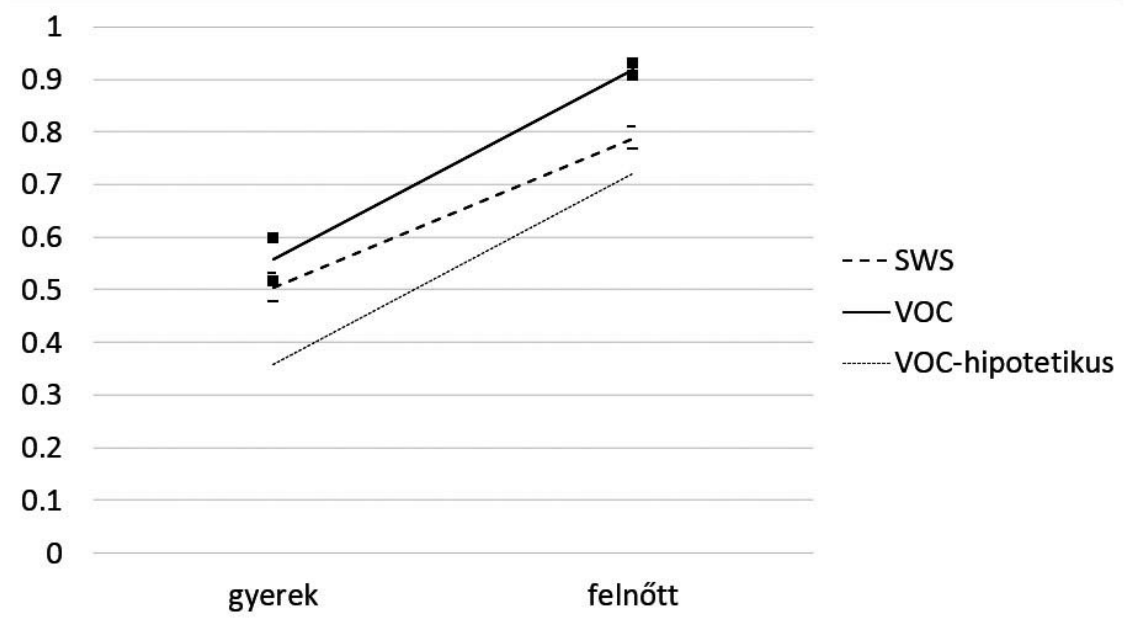

6. ábra. A szinuszhullámú, illetve hatsávos amplitúdómodulált ingerek teljesítményviszonya (felsố két szakasz), illetve a négysávos amplitúdómodulált ingerekkel kapcsolatban feltételezett eredmények (legalsó szakasz). A valós adatoknál a standard hibákat is jelöltük. A hipotetikus vonal és a szaggatott vonal végpontjai közti különbségek hasonlítanak Nittrouer és munkatársai eredményeire

san kialakuló gyakorlási hatásnak is, tehát hogy új szintetizált mondatok észlelése az elôzetes gyakorlás hatására fokozatosan javul. Ez a hatás már egyértelmúen a tanulási transzferrel kapcsolatos, azonban csak felnôtteknél figyelhetố meg, gyerekeknél nem. Sốt, a felnốttek is csak a szinuszhullámú ingerek esetén mutatták, a VOC ingereknél nem (valószínúleg a felnôtt VOC csoportban a plafonhatás miatt nem kaptuk meg a szignifikáns javulást). A szinuszhullámú ingereknél viszont érdekes, hogy a felnôtt csoportban már nyolc próba során is megfigyelhetố a gyakorlási hatás; ennek kimutatása azonban összetett elemzést igényelt, melynek során a mondatok változó nehézségének hatását ki kellett szúrni. Ezt a rövid távú tanulási hatást Nittrouer és munkatársai nem vizsgálták, így ez - ismereteink szerint - új eredménynek tekinthetô.

Mondataink nehézségével kapcsolatban megjegyzendô, hogy nem a szigorúan kiegyenlített nehézségú ingerekre törekedtünk, hanem elsôsorban arra, hogy a csak elnagyoltan hasonló szerkezetú mondatok az óvodás kísérleti személyeink figyelmét lekössék, bevonódásukat elôsegítsék. A mondatnehézségek közti különbségeket és azok okait utólagos elemzéssel igyekeztünk föltárni. Ezzel kapcsolatban két megfigyelést fontos említeni. Egyrészt, mint a 4. ábrán látható, a mondatok nehézségi profilját alapvetốen a szintézis típusa befolyásolta, és nem az életkor. Másrészt a mondatmegértés során fellépố szemantikai restaurációs hatások tetten érhetôek abban, hogy az elsố fốnévi csoport értelmezésének sikere erôsen összefügg a mondat többi részének megértésével.

További terveink között szerepel az ingerek alaposabb kalibrálása, a mondatok nyelvi nehézségének alaposabb kontrollja és valamivel több próba használata a kísér- 
leti ülésekben. Ezekkel a módosításokkal a fent említett perceptuális tanulási hatást kívánjuk tisztább, egyértelmúbb formában kimutatni. Ezen kívül a kisebb nyelvi egységek (szavak, álszavak, szótagok) vizsgálatát, illetve atipikus fejlôdésú csoportok bevonását is tervezzük.

\section{KÖSZÖNETNYILVÁNÍTÁS}

A kézirat szerzői köszönetüket fejezik ki az ELTE Bárczi Gusztáv Gyógypedagógiai Kar munkatársainak, elsôsorban Keresztessy Évának, a kar audioeszközeinek és hallásvizsgáló laborjának rendelkezésre bocsátásáért, valamint a Rákosmenti Mákvirág és a Rákosmenti Robogó óvoda vezetôinek, Horváth Máriának és Kiss Csabánénak, a gyermek kísérleti személyek és a vizsgálatok helyszínének biztosításáért. 
Jakab Zoltán és mtsai

Függelék. A vizsgálatban használt ingerek

\begin{tabular}{|l|l|l|}
\hline $\begin{array}{l}\text { Tréning próbák } \\
\text { alapmondatai }\end{array}$ & Szórendi változat & Szemantikai változat \\
\hline $\begin{array}{l}\text { A csibész kölyök betörte } \\
\text { az ablakot a labdával. (NF) }\end{array}$ & $\begin{array}{l}\text { Az ablakot a csibész kölyök } \\
\text { betörte a labdával. }\end{array}$ & $\begin{array}{l}\text { A jó gyerek betörte az ablakot } \\
\text { a labdával. }\end{array}$ \\
\hline $\begin{array}{l}\text { A macska elbújt a nagymama } \\
\text { ágyában. (NF) }\end{array}$ & $\begin{array}{l}\text { A nagymama ágyában bújt el } \\
\text { a macska. }\end{array}$ & $\begin{array}{l}\text { A kutya bebújt a nagymama } \\
\text { ágya alá. }\end{array}$ \\
\hline Éles próbák alapmondatai & Szórendi változat & Szemantikai változat \\
\hline $\begin{array}{l}\text { A harapós kutya elkergette } \\
\text { a medvét a kertbôl. (F) }\end{array}$ & $\begin{array}{l}\text { A medvét a harapós kutya } \\
\text { elkergette a kertból. }\end{array}$ & $\begin{array}{l}\text { A harapós kutyát a medve } \\
\text { elkergette a kertból. }\end{array}$ \\
\hline $\begin{array}{l}\text { A tanító néni mindenkinek } \\
\text { adott egy kis ajándékot. (F) }\end{array}$ & $\begin{array}{l}\text { Mindenkinek adott egy kis } \\
\text { ajándékot a tanító néni. }\end{array}$ & $\begin{array}{l}\text { A tanító néninek mindenki } \\
\text { adott egy kis ajándékot. }\end{array}$ \\
\hline $\begin{array}{l}\text { Péter vendégül látta barátait } \\
\text { a nagy sátorban. (F) }\end{array}$ & $\begin{array}{l}\text { A nagy sátorban Péter } \\
\text { vendégül látta a barátait. }\end{array}$ & $\begin{array}{l}\text { A barátai vendégül látták } \\
\text { Pétert a nagy sátorban. }\end{array}$ \\
\hline $\begin{array}{l}\text { A kéményseprố kölcsönadta } \\
\text { a kabátját a kisfiúnak. (F) }\end{array}$ & $\begin{array}{l}\text { A kabátját a kéményseprố } \\
\text { kölcsönadta a kisfiúnak. }\end{array}$ & $\begin{array}{l}\text { A kisfiú kölcsönadta a } \\
\text { kabátját a kéményseprónek. }\end{array}$ \\
\hline $\begin{array}{l}\text { Eszter biciklit szeretne } \\
\text { születésnapjára. (NF) }\end{array}$ & $\begin{array}{l}\text { Születésnapjára Eszter biciklit } \\
\text { szeretne. }\end{array}$ & $\begin{array}{l}\text { Eszter biciklit szeretne venni } \\
\text { a testvérének. }\end{array}$ \\
\hline $\begin{array}{l}\text { Az elefánt elbújt a fa mögé. } \\
\text { (NF) }\end{array}$ & A fa mögé bújt el az elefánt. & Az elefánt a fa mellett áll. \\
\hline $\begin{array}{l}\text { Minden gyerek megette } \\
\text { a spenótot. (NF) }\end{array}$ & $\begin{array}{l}\text { A spenótot minden gyerek } \\
\text { megette. }\end{array}$ & $\begin{array}{l}\text { Minden gyerek utálja a } \\
\text { spenótot. }\end{array}$ \\
\hline $\begin{array}{l}\text { A ravasz róka megszerezte } \\
\text { a finom sajtot. (NF) }\end{array}$ & $\begin{array}{l}\text { A finom sajtot a ravasz róka } \\
\text { szerezte meg. }\end{array}$ & $\begin{array}{l}\text { A ravasz róka eldugta a finom } \\
\text { sajtot. }\end{array}$ \\
\hline
\end{tabular}




\section{FELHASZNÁLT IRODALOM}

Bent, T., Loebach, J., L., Phillips, L., \& Pisoni, D., B. (2011). Perceptual adaptation to sinewave-vocoded speech across languages. Journal of experimental psychology. Human perception and performance, 37(5): 1607-1616.

Bregman, A., S. (1990). Auditory Scene Analysis. Cambridge Mass: The MIT Press.

Canepari, L. (2007). Natural Phonetics and Tonetics. LINCOM Publishers.

Cherry, C. (1953). Some experiments on the recognition of speech with one and with two ears. Journal of the Acoustical Society of America, 25, 975-979.

Gósy M. (1995). GMP-Diagnosztika. A beszédészlelés és a beszédmegértés folyamatának vizsgálata. Budapest: NIKOL Kiadó.

Gósy M. (2005). Pszicholingvisztika. Budapest: Osiris Kiadó.

Hervais-Adelman, A., G., Davis, M., H., Johnsrude, I., S., Taylor, K., J., \& Carlyon, R., P. (2011). Generalization of perceptual learning of vocoded speech. Journal of experimental psychology. Human perception and performance, 37(1), 283-295.

Hillenbrand, J., M., Clark, M., J., \& Baer, C., A. (2011). Perception of sinewave vowels. Journal of the Acoustical Society of America, 129(6), 3991-4000.

Honbolygó, F. (2007a). A hallási objektumok észlelése. In: Csépe V., Gyôri M. \& Ragó A. (szerk.), Általános pszichológia I. Észlelés és figyelem (pp. 307-351). Budapest: Osiris Kiadó.

Honbolygó, F. (2007b). A beszéd észlelése. In: Csépe V., Győri M. \& Ragó A. (szerk.), Általános pszichológia I. Észlelés és figyelem (pp. 352-386). Budapest: Osiris Kiadó.

Johnson, K. (2011). Speech perception. In: Acoustic and Auditory Phonetics. 3rd edition (pp. 118-150). Hoboken, NJ: Wiley-Blackwell.

Kas B., Lőrik J., M. Bogáth R., Sz. Vékony A., \& Mályi N. (2012). SZÓL-E? Szúröeljárás az óvodáskori logopédiai ellátáshoz. Budapest: Logotech Kiadó.

Kovács, I., \& Eisenberg, M. (2004) Human development of binocular rivalry. In: Binocular Rivalry (pp. 101-116). Cambridge Mass: The MIT Press.

Ladefoged, P., \& Broadbent, D., E. (1957). Information conveyed by vowels. Journal of the Acoustical Society of America, 29, 98-104.

Lowenstein, J., H., Nittrouer, S., \& Tarr. E. (2012). Children weight dynamic spectral structure more than adults: Evidence from equivalent signals. Journal of the Acoustical Society of America, 132(6), EL443-EL449.

Mooney, C. M. (1957). Age in the development of closure ability in children. Canadian Journal of Psychology, 1, 219-228.

Morrongiello, B., A., Robson, R., C., \& Best, C., T. (1984). Trading relations in the perception of speech by 5-year-old children. Journal of Experimental Child Psychology, 37, 231-250.

Newman, R., S., Chatterjee, M., Morini, G., \& Nasuta, M. (2013). Toddlers' comprehension of noise-vocoded speech and sine-wave analogs to speech. Proceedings of Meetings on Acoustics, Vol., 19 (ICA 2013, Montreal), http://acousticalsociety.org/

Nilsson, M., Soli, S. D., \& Gelnett, D. J. (1996). Development and norming of a hearing in noise test for children. Los Angeles, CA: House Ear Institute.

Nilsson, M., Soli, S. D., \& Sullivan, J. A. (1994). Development of the hearing in noise test for the measurement of speech reception thresholds in quiet and in noise. Journal of the Acoustical Society of America, 95, 1085-1099.

Nittrouer, S., \& Lowenstein, J., H. (2009). Does harmonicity explain children's cue weighting of fricative-vowel syllables? Journal of the Acoustical Society of America, 125(3), 1679-1692.

Nittrouer, S., \& Lowenstein, J., H. (2010). Learning to perceptually organize speech signals in native fashion. Journal of the Acoustical Society of America, 127(3), 1624-1635. 
Nittrouer, S., Lowenstein, J., H., \& Packer, R. (2009). Children discover the spectral skeletons in their native language before the amplitude envelopes. Journal of Experimental Psychology Human Perception E Performance, 35(4), 1245-1253.

Pléh Cs., \& Sinkovics B. (2011). A szórend és a fókuszbaemelés hatása a magyar mondatok emlékezeti leképezésében. Magyar Pszichológiai Szemle, 66(2), 321-333.

Remez, R. (2005). Perceptual Organization of Speech. In: Pisoni, D. B., \& Remez, R. E. (Eds), Handbook of Speech Perception. Oxford: Blackwell.

Remez, R., E., \& Rubin, P., E. (1990). On the perception of speech from time-varying acoustic information: Contributions of amplitude variation. Perception $\mathcal{E}$ Psychophysics, 48(4), 313-325.

Remez, R., E., Rubin. P., E., Pisoni, D., B., \& Carrell, T., D. (1981). Speech perception without traditional speech cues. Science, 212, 947-950.

Remez, R., E., Rubin, P., E., Nygaard, L., C., \& Howell, W., A. (1987): Perceptual normalization of vowels produced by sinusoidal voices. Journal of Experimental Psychology Human Perception $\mathcal{E}^{\circ}$ Performance, 13(1) 40-61.

Remez, R., E, Rubin, P., E., Berns, S., M., Pardo, J., S., \& Lang, J., M. (1994): On the perceptual organization of speech. Psychological Review, 101(1), 129-156.

Repp, B., H. (1982): Phonetic trading relations and context effects: new experimental evidence for a speech mode of perception. Psychological Bulletin, 92(1), 81-110.

Rosen, S., \& Hui, S., N., C. (2015). Sine-wave and noise-vocoded sine-wave speech in a tone language: acoustic details matter. Journal of the Acoustical Society of America, 138, 3698-3702.

Rosner, B., S., Talcott, J., B., Witton, C., Hogg, J., D., Richardson, A., J., Hanson, P., C., \& Stein, J., F. (2003). The perception of "sine-wave speech" by adults with developmental dyslexia. Journal of Speech, Language and Hearing Research, 46, 68-79.

Samuel, A., G., \& Kat, D. (1996) Early levels of analysis of speech. Journal of Experimental Psychology Human Perception E Performance, 22(3), 676-694.

Schwartz, J., Grimault N., Hupe, J., Moore, B., J., C., \& Pressnitzer, D. (2012). Multistability in perception: binding sensory modalities, an overview. Philosophical Transactions of the Royal Society B, 367, 896-905.

Shannon, R. V., Zeng, F. G., Kamath, V., Wygonski, J., \& Ekelid, M.(1995). Speech recognition with primarily temporal cues. Science, 270, 303-304.

Vargha A. (2000). Matematikai statisztika pszichológiai, nyelvészeti és biológiai alkalmazásokkal. Budapest: Pólya Kiadó. 


\title{
PERCEPTION OF SINE-WAVE AND AMPLITUDE-MODULATED SENTENCES IN HUNGARIAN
}

\author{
JAKAB, ZOLTÁN - NAGYNÉ RINGER, GABRIELLA - VÍG, JULIANNA - \\ SZABÓ, PÁL TAMÁS
}

\begin{abstract}
Aims and scope: In the present study we used reduced speech stimuli to examine speech perception in 5-6year-old children and adults.

Method: We used audiorecorded Hungarian sentences to synthetize sine-wave and vocoded versions of those sentences.

Results: Similarly to earlier developmental studies using English-language stimuli we found that both age groups performed well in understanding these forms of synthetized speech, and adults performed better than children. However, we found a pattern slightly different from the English data regarding the relation between SWS and VOC stimuli. While in studies using English stimuli children perfomed better at SWS than VOC stimuli, and the reverse relationship was observed in adults, we found equal performance for the two types of stimuli in children, and an advantage for VOC stimuli in adults. Lexical restoration was indicated by the finding that recognition of the first noun phrases in the sentences correlated strongly with recognition of the remaining part in both age groups, and both types of synthesis.

Conclusion: We reproduced some basic findings obtained in studies using English-language stimuli. As a novel finding we separated two types of perceptual learning that occurred in our sessions: the well-known type of instant perceptual learning, and a more gradual improvement over the course of the subsequent trials that reflected learning transfer between the stimuli. However, while instant perceptual learning was observable in both age groups, transfer-based improvement we only found in the adult group.
\end{abstract}

Keywords: Sine-wave speech, amplitude-modulated speech, speech perception, perceptual learning 